Article

\title{
Fuel reforming over Ni-based catalysts coupled with selective catalytic reduction of $\mathrm{NO}_{x}$
}

\author{
ZHAO Jiaojiao, YU Yunbo*, HAN Xue, HE Hong \\ Research Center for Eco-Environmental Sciences, Chinese Academy of Sciences, Beijing 100085, China
}

\section{A R T I C L E I N F O}

Article history:

Received 7 February 2013

Accepted 2 April 2013

Published 20 July 2013

\section{Keywords:}

Catalytic reforming

Ni-based catalyst

Nitrogen oxide

Selective catalytic reduction

Silver

Alumina

\begin{abstract}
A B S T R A C T
$\mathrm{La}_{2} \mathrm{O}_{2} \mathrm{CO}_{3}, \mathrm{CeO}_{2}, \mathrm{ZrO}_{2}$, and $\mathrm{Al}_{2} \mathrm{O}_{3}$ supported $\mathrm{Ni}$ catalysts were prepared by an impregnation method and employed for reforming of $n$-dodecane to simultaneously produce low molecular weight hydrocarbons (HCs) and $\mathrm{H}_{2}$. These reforming products served as reductants and promoters for the selective catalytic reduction (SCR) of $\mathrm{NO}_{x}$ over $\mathrm{Ag} / \mathrm{Al}_{2} \mathrm{O}_{3}$. $\mathrm{N}_{2}$ adsorption-desorption, X-Ray powder diffraction, $\mathrm{H}_{2}$ temperature programmed reduction, and thermogravimetric analysis were performed for Ni-based catalysts. It was shown that an increase in the redox performance of Ni-based catalysts enhanced the $\mathrm{H}_{2}$ production from fuel reforming but decreased the amount of HCs available for further SCR reaction. The temperature window for $\mathrm{NO}_{x}$ removal using the coupled system shifted to lower temperatures at the expense of the $\mathrm{NO}_{x}$ conversion. An optimal ratio of $\mathrm{H}_{2} / \mathrm{HCs}$ was achieved using a $\mathrm{Ni} / \mathrm{ZrO}_{2}+\mathrm{Ag} / \mathrm{Al}_{2} \mathrm{O}_{3}$ dual catalyst system, which exhibited high activity for $\mathrm{NO}_{x}$ conversion at typical diesel exhaust temperatures. Studies on the durability and performance of this $\mathrm{Ni} / \mathrm{ZrO}_{2}+\mathrm{Ag} / \mathrm{Al}_{2} \mathrm{O}_{3}$ coupled system were also performed, and the results showed that the lifetime of the reforming catalyst may limit the system and requires further improvement.
\end{abstract}

(C) 2013, Dalian Institute of Chemical Physics, Chinese Academy of Sciences. Published by Elsevier B.V. All rights reserved.

\section{Introduction}

Diesel engines are currently popular in industry and motor vehicles because of their excellent power performance and cost effectiveness. However, the issue of $\mathrm{NO}_{x}$ removal from diesel engine exhaust remains a major barrier to more widespread usage. The lean-burn characteristics of diesel engines results in low efficiency for $\mathrm{NO}_{x}$ reduction by three-way catalysts [1], as selective catalytic reduction (SCR) of $\mathrm{NO}_{x}$ exhibits highest performance in oxygen-rich conditions. Because of its superior $\mathrm{NO}_{x}$ removal efficiency, an urea/ $\mathrm{NH}_{3}$-SCR system has been commercially used in Europe, the United States, and Japan. However, this complex exhaust treatment facility is expensive and has potential for secondary pollution caused by $\mathrm{NH}_{3}$ leakage [2]. To avoid these problems, hydrocarbon (HC)-SCR technology that employs on-board fuel as the source of reductant has drawn considerable interest in recent years.

It has been demonstrated that numerous catalysts such as zeolitic oxide, base metal/oxides, and noble metal catalysts are effective for $\mathrm{NO}_{x}$ removal by HC-SCR in the presence of excess oxygen [2-6]. Among them, alumina-supported silver $\left(\mathrm{Ag} / \mathrm{Al}_{2} \mathrm{O}_{3}\right)$ is a particularly promising catalyst for practical application [1,7-9]. The $\mathrm{NO}_{x}$ abatement efficiency of HC-SCR not only depends on the nature of the catalysts but also on the structure and composition of the reductants used [8-12]. Generally, the efficiency of reductants for $\mathrm{NO}_{x}$ removal over

\footnotetext{
*Corresponding author. Tel/Fax: +86-10-62849121; E-mail: ybyu@rcees.ac.cn This work was supported by the National Natural Science Foundation of China (21177142), the National Basic Research Program of China (973 Program, 2010CB732304), and the National High Technology Research and Development Program of China (863 Program, 2013AA065301).
} DOI: 10.1016/S1872-2067(12)60598-1 | http://www.sciencedirect.com/science/journal/18722067 | Chin. J. Catal., Vol. 34, No. 7, July 2013 
$\mathrm{Ag} / \mathrm{Al}_{2} \mathrm{O}_{3}$ drops in the sequence of oxygenated HCs (alcohols, aldehydes, ketones etc.) > linear paraffins $>$ branched paraffins $>$ cycloalkanes. For linear paraffins, the light-off temperature for $\mathrm{NO}_{x}$ reduction decreases with increasing chain length. It has been reported that the light-off temperature for $\mathrm{NO}_{x}$ reduction using a $2 \% \mathrm{Ag} / \mathrm{Al}_{2} \mathrm{O}_{3}$ catalyst decreased from $675 \mathrm{~K}$ to $525 \mathrm{~K}$ as chain length was decreased from $\mathrm{C}_{8}$ to $\mathrm{C}_{1}$ [8]. Higher normal alkanes exhibited higher reaction rates for $\mathrm{NO}_{x}$ reduction but decreased values of maximum $\mathrm{NO}_{x}$ conversion [13]. Under $\mathrm{HC} / \mathrm{NO}_{x}$ ratio of 6 , gas hourly space velocity (GHSV) of 60000 $\mathrm{h}^{-1}$, the activity of $2 \% \mathrm{Ag} / \mathrm{Al}_{2} \mathrm{O}_{3}$ for $\mathrm{NO}_{x}$ reduction by $\mathrm{C}_{8} \mathrm{H}_{18}$ was tested by Eränen et al. [14], during which about $90 \% \mathrm{NO}_{x}$ conversion was achieved in a temperature range of 720-770 K. With $n$-dodecane as a reductant, Yoon et al. [15] achieved the highest $\mathrm{NO}_{x}$ conversion of ca. $75 \%$ over $2 \% \mathrm{Ag} / \mathrm{Al}_{2} \mathrm{O}_{3}$ (GHSV = $30000 \mathrm{~h}^{-1}$ ). When $n-\mathrm{C}_{16} \mathrm{H}_{34}$ or diesel was applied as a reductant directly, the highest $\mathrm{NO}_{x}$ conversion over $1.9 \% \mathrm{Ag} / \mathrm{Al}_{2} \mathrm{O}_{3}$ was only $50 \%\left(\mathrm{HC} / \mathrm{NO}_{x}=6\right.$, GHSV $\left.=60000 \mathrm{~h}^{-1}\right)$ [16]. Rapid deactivation of $\mathrm{Ag} / \mathrm{Al}_{2} \mathrm{O}_{3}$ because of serious carbon deposition was observed when diesel such as gas-to-liquid (GTL, negligible sulphur and only $0.3 \mathrm{wt} \%$ aromatics) and US06 (ultra-low sulphur but $24 \mathrm{wt} \%$ aromatics) were used directly as a reductant for $\mathrm{NO}_{x}$ conversion and the catalyst even failed to reach a steady state [10]. In contrast, when using small molecular weight $\mathrm{HCs}$ as reductants (e.g., $\mathrm{C}_{3} \mathrm{H}_{6}$ ), up to $90 \% \mathrm{NO}_{x}$ conversion was achieved using a $\mathrm{Ag} / \mathrm{Al}_{2} \mathrm{O}_{3}$ catalyst over a wide temperature range (700-850 K) [17]. Using ethanol or methanol as reductants, $\mathrm{NO}_{x}$ conversion over $5 \% \mathrm{Ag} / \mathrm{Al}_{2} \mathrm{O}_{3}$ catalysts in the range $600-700 \mathrm{~K}$ was as high as $100 \%$ [18]. Diesel engine bench testing has confirmed that a system of $\mathrm{Ag} / \mathrm{Al}_{2} \mathrm{O}_{3}-\mathrm{C}_{2} \mathrm{H}_{5} \mathrm{OH}$ showed outstanding $\mathrm{NO}_{x}$ conversion and good durability [19]. A comparison between $\mathrm{NO}_{x}$ reductions over $\mathrm{AgAlO}{ }_{2} / \mathrm{Al}_{2} \mathrm{O}_{3}$ with diesel fuel and by partial oxidation products of diesel was performed by Nakatsuji et al. [20]. The results showed that partial oxidation products (small molecular weight HCs such as acetaldehyde) exhibited higher activity for $\mathrm{NO}_{x}$ removal than diesel itself. These results demonstrate that small molecular weight $\mathrm{HCs}$ and oxygenated ones are preferable for $\mathrm{NO}_{x}$ reduction over $\mathrm{Ag} / \mathrm{Al}_{2} \mathrm{O}_{3}$ catalysts.

Although $\mathrm{H}_{2}$ is active for SCR of $\mathrm{NO}_{x}$ over precious metal catalysts at low temperatures [21], for $\mathrm{Ag} / \mathrm{Al}_{2} \mathrm{O}_{3}$ catalysts, $\mathrm{H}_{2}$ is not an efficient reductant [22-24]. However, the research of Satokawa [25] noted that a small amount of $\mathrm{H}_{2}$ could significantly improve the activity of $\mathrm{Ag} / \mathrm{Al}_{2} \mathrm{O}_{3}$ for $\mathrm{NO}_{x}$ reduction by $\mathrm{C}_{3} \mathrm{H}_{8}$ at low temperatures. Since then, considerable attention has been paid to the effect of $\mathrm{H}_{2}$ on the HC-SCR reaction. During this reaction, it was proposed that the role of $\mathrm{H}_{2}$ in $\mathrm{NO}_{x}$ reduction is related to the catalyst, reductant, and concentration of added $\mathrm{H}_{2}$ [26-30]. Zhang et al. [31] reported that the presence of $\mathrm{H}_{2}$ at $1 \%$ significantly enhanced the low temperature activity of $4 \% \mathrm{Ag} / \mathrm{Al}_{2} \mathrm{O}_{3}$ for $\mathrm{NO}_{x}$ reduction by $\mathrm{C}_{3} \mathrm{H}_{6}$ at a GHSV of 50000 $\mathrm{h}^{-1}$ and a $\mathrm{HC} / \mathrm{NO}_{x}$ ratio of 6 . In this case, $80 \% \mathrm{NO}_{x}$ conversion was achieved over a wider range of temperatures (500-800 K) than in the absence of $\mathrm{H}_{2}(650-800 \mathrm{~K})$. To overcome the difficulties and potential dangers of $\mathrm{H}_{2}$ storage and transportation, in situ $\mathrm{H}_{2}$ generation by on-board fuel reforming is highly desirable for the application of solid-oxide fuel cells in vehicles
[32-36]. The promotion of $\mathrm{NO}_{x}$ removal by HC-SCR at low temperatures in exhaust aftertreatment systems would also be advantageous [11,37]. During the catalytic reforming process, the metal nickel $(\mathrm{Ni})$ has been extensively utilized as an active component because of its superior $\mathrm{C}-\mathrm{C}$ bond cleavage ability, low cost, and ready availability [38,39]. The catalytic performance of Ni-based catalysts, such as the distribution of reforming products and durability, has been found to be closely related to the nature of the support [40-42]. Such features provide an opportunity for simultaneous generation of $\mathrm{H}_{2}$ and small molecular HCs if Ni-based catalysts were to be used in catalytic reforming of on-board fuel.

Inspired by the previous works, catalytic reforming of $n$-dodecane by Ni-based catalysts (representative of on-board fuel) was investigated, producing both $\mathrm{H}_{2}$ and small molecular $\mathrm{HCs}$. This system was coupled with a $4 \mathrm{wt} \% \mathrm{Ag} / \mathrm{Al}_{2} \mathrm{O}_{3}$ catalyst for HC-SCR, and the influence of the different supports employed in Ni-based catalysts on $\mathrm{NO}_{x}$ conversion was examined under a simulated atmosphere.

\section{Experimental}

\subsection{Catalyst preparation}

All materials were analytical reagent grade purchased from Sinopharm Chemical Reagent Co., Shanghai, China. Metal oxides (La, Ce, and $\mathrm{Zr}$ ) were prepared by a homogeneous precipitation method with the corresponding metal nitrate as precursor and urea as the precipitant [43]. The precipitates were dried in an oven at $373 \mathrm{~K}$ overnight and were then calcined at $873 \mathrm{~K}$ for $5 \mathrm{~h}$ in air. Utilizing the above metal oxides and commercial boehmite as supports, $5 \mathrm{wt} \% \mathrm{Ni}$-based catalysts were prepared using an impregnation method. Specifically, a certain amount of support $(5 \mathrm{~g})$ was added into a $\mathrm{Ni}\left(\mathrm{NO}_{3}\right)_{2}$ solution $(50 \mathrm{ml}, 0.085$ $\mathrm{mol} / \mathrm{L}$ ) and stirred at room temperature for $1 \mathrm{~h}$, and then the excess water was removed by rotary evaporation at $333 \mathrm{~K}$ under vaccum condition. The resulting solids were dried at $373 \mathrm{~K}$ overnight and then calcined at $873 \mathrm{~K}$ for $3 \mathrm{~h}$ in air. Before measurement, the samples were crushed and sieved to ensure that particles were between 20 and 40 mesh in size.

As described elsewhere [12], $4 \mathrm{wt} \% \mathrm{Ag} / \mathrm{Al}_{2} \mathrm{O}_{3}$ catalyst was prepared by an impregnation method, immersing boehmite into an aqueous solution of $\mathrm{AgNO}_{3}$.

\subsection{Catalyst characterization}

Powder X-ray diffraction (XRD) was performed using an X' Pert Pro type diffractometer (PANalytical, Netherlands) with a $\mathrm{Cu} K_{\alpha}$ source $(\lambda=0.154056 \mathrm{~nm})$. The patterns were measured over a $2 \theta$ range of $10^{\circ}-90^{\circ}$ with a scan speed of $4^{\circ} / \mathrm{min}$.

The specific surface area and pore characterization of the catalysts were obtained by $\mathrm{N}_{2}$ adsorption/desorption analysis at $77 \mathrm{~K}$ using a Quadrasorb-18 automated gas sorption analyzer (Quantachrome, USA). Prior to $\mathrm{N}_{2}$ physisorption, the catalysts were degassed at $573 \mathrm{~K}$ for $5 \mathrm{~h}$.

Hydrogen temperature-programmed reduction $\left(\mathrm{H}_{2}\right.$-TPR) was performed on an AutoChem II 2920 type chemisorption 
analyzer (Micromeritics, USA) using $10 \% \mathrm{H}_{2} / \mathrm{Ar}$ within a temperature range of 323-1273 $\mathrm{K}$ and a ramp rate of $10 \mathrm{~K} / \mathrm{min}$.

Thermogravimetric analysis (TG) of used samples was carried out on a TGA/DSC 1 (STARe System, Mettler Toledo USA) in an $\mathrm{O}_{2}$ atmosphere within a temperature range of 300-1000 $\mathrm{K}$ at a ramp rate of $20 \mathrm{~K} / \mathrm{min}$.

\subsection{Activity test}

n-dodecane $\left(n-\mathrm{C}_{12} \mathrm{H}_{26}\right.$, analytical reagent grade, $99.8 \%$, Tianjin Fuchen Chemical Reagents Factory, China) was chosen to be representative of on-board diesel for catalytic reforming. Activity testing was carried out on a fixed-bed continuous evaluation equipment controlled by a computer. Two tubular furnaces were employed in the evaluation equipment, in which the former one with two heating areas worked for evaporating liquid reactants and reforming reaction, and the latter one worked for SCR reaction. The liquid reactants of $n$-dodecane and water for the reforming reaction were precisely controlled by micropumps (HARVARD, PHD 2000 Infusion), with injection rates of 13 and $30 \mu \mathrm{l} / \mathrm{min}$, respectively. The reagents were volatilized at $573 \mathrm{~K}$, and the gas was fed into the catalyst bed by a stream of $\mathrm{N}_{2}$ at $1 \mathrm{~atm}$ with a flow rate of $205 \mathrm{ml} / \mathrm{min}$. Conditions for reforming were set as follows: $\mathrm{H}_{2} \mathrm{O} / \mathrm{O}_{2} / \mathrm{C}=2.45 / 0.5 / 1$ (ca. $2.2 \%$ $\left.\mathrm{O}_{2}\right), \mathrm{N}_{2}$ balance, $W / F=0.072(\mathrm{~g} \cdot \mathrm{s}) / \mathrm{ml}$, reaction temperature $773 \mathrm{~K}$. After being condensed by an equipment with a circular outline (the temperature of which was set at $273 \mathrm{~K}$ ), the gas phase reforming products were then introduced into the SCR reaction zone, in which the reaction conditions were set as follows: $\mathrm{NO}_{x} 0.1 \%, \mathrm{O}_{2} 10 \%, \mathrm{~N}_{2}$ balance, $W / F=0.018(\mathrm{~g} \cdot \mathrm{s}) / \mathrm{ml}$. The concentrations of $\mathrm{NO}$ and $\mathrm{NO}_{2}$ were detected by a Fourier transform infrared spectrometer equipped with a gas cell (Nicolet is $10,0.2 \mathrm{dm}^{3}$ gas cell, $393 \mathrm{~K}$ ), and each data point was recorded after stabilization at the preset temperature for 35 min. The concentrations of $\mathrm{H}_{2}, \mathrm{CO}_{2}$, and total $\mathrm{HCs}$ before and after the SCR reaction were measured by a gas chromatograph (GC, Shimadzu, GC-2014C) equipped with two thermal conductivity detectors (TCD) and one flame ionization detector (FID). Gas of $\mathrm{O}_{2}, \mathrm{~N}_{2}, \mathrm{CO}_{2}$, and $\mathrm{C}_{2} \mathrm{H}_{4}$ flow through Porpack-N column (80-100 mesh, $3.2 \mathrm{~mm} \times 2.1 \mathrm{~mm} \times 1.0 \mathrm{~m}$ ) and were detected by TCD1; $\mathrm{H}_{2}$ flow through MS-13X column (80-100 mesh, $3.2 \mathrm{~mm}$ $\times 2.1 \mathrm{~mm} \times 2.0 \mathrm{~m}$ ) and was detected by TCD2; oxygenated HCs such as $\mathrm{CH}_{3} \mathrm{CH}_{2} \mathrm{OH}$ and $\mathrm{CH}_{3} \mathrm{COCH}_{3}$ were separated by Rtx-Wax capillary column $(0.53 \mathrm{~mm} \times 1 \mu \mathrm{m} \times 30 \mathrm{~m})$ and deteted by FID. The simplified flow path of the coupling system is shown in Fig. 1.

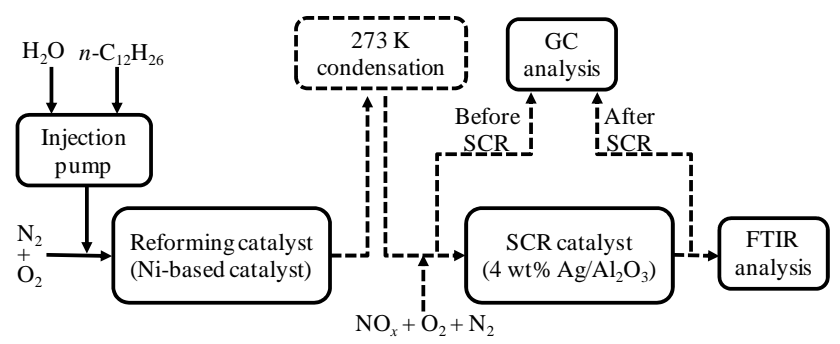

Fig. 1. Simplified flow path of the coupling system. The solid line represents heating insulation and the dashed one represents condensation.



Fig. 2. XRD patterns of Ni-based catalysts supported on different oxides.

\section{Results and discussion}

\subsection{Structural properties}

Figure 2 displays the XRD patterns of Ni-based catalysts supported on different oxides. Supports prepared by homogeneous precipitation were present as $\mathrm{La}_{2} \mathrm{O}_{2} \mathrm{CO}_{3}$ (JCPDS 84-1963) with hexagonal structure, $\mathrm{CeO}_{2}$ (JCPDS 43-1002) with cerianite structure, and $\mathrm{ZrO}_{2}$ as a composite of tetragonal (JCPDS 50-1089) and monoclinic (JCPDS 37-1484) structures, respectively. After $5 \% \mathrm{Ni}$ was loaded, weak $\mathrm{NiO}$ features (JCPDS 04-0850) were detected, indicating a good dispersion of $\mathrm{Ni}$ species. The $\mathrm{Ni} / \mathrm{Al}_{2} \mathrm{O}_{3}$ catalyst prepared from boehmite exhibited the characteristic patterns of $\mathrm{NiAl}_{2} \mathrm{O}_{4}$ (JCPDS 10-0339) and $\mathrm{Al}_{2} \mathrm{O}_{3}$ (JCPDS 74-2206) simultaneously. The specific surface area and pore structural parameters of the Ni-based reforming catalysts are listed in Table 1 . Compared with the $5 \% \mathrm{Ni} / \mathrm{Al}_{2} \mathrm{O}_{3}$ catalyst, samples prepared by the homogeneous precipitation method gave lower surface area and smaller pore volume and diameter.

\subsection{Catalytic performance}

The activity of the Ni-based catalyst $+\mathrm{Ag} / \mathrm{Al}_{2} \mathrm{O}_{3}$ coupled system for $\mathrm{NO}_{x}$ reduction is shown in Fig. 3. For comparison, $n$-dodecane was used directly as a reductant for $\mathrm{NO}_{x}$ removal over $\mathrm{Ag} / \mathrm{Al}_{2} \mathrm{O}_{3}$ (hereafter denoted as $n-\mathrm{C}_{12} \mathrm{H}_{26}$-SCR), during which $\mathrm{NO}_{x}$ conversion was only $5 \%$ at $525 \mathrm{~K}$. The high light-off characteristics of $n$-dodecane for $\mathrm{NO}_{x}$ reduction may be at-

\section{Table 1}

Specific surface area and pore structural parameters of Ni-based catalysts supported on different oxides.

\begin{tabular}{lccc}
\hline Sample & $\begin{array}{c}\text { Specific surface } \\
\text { area }\left(\mathrm{m}^{2} / \mathrm{g}\right)\end{array}$ & $\begin{array}{c}\text { Average pore } \\
\text { diameter }(\mathrm{nm})\end{array}$ & $\begin{array}{c}\text { Pore volume } \\
\left(10^{-2} \mathrm{~cm}^{3} / \mathrm{g}\right)\end{array}$ \\
\hline $5 \% \mathrm{Ni} / \mathrm{La}_{2} \mathrm{O}_{2} \mathrm{CO}_{3}$ & 10.5 & 2.9 & 7.5 \\
$5 \% \mathrm{Ni} / \mathrm{CeO}_{2}$ & 31.4 & 1.1 & 8.3 \\
$5 \% \mathrm{Ni} / \mathrm{ZrO}_{2}$ & 15.6 & 4.8 & 3.7 \\
$5 \% \mathrm{Ni} / \mathrm{Al}_{2} \mathrm{O}_{3}$ & 282.6 & 6.4 & 9.0 \\
\hline
\end{tabular}




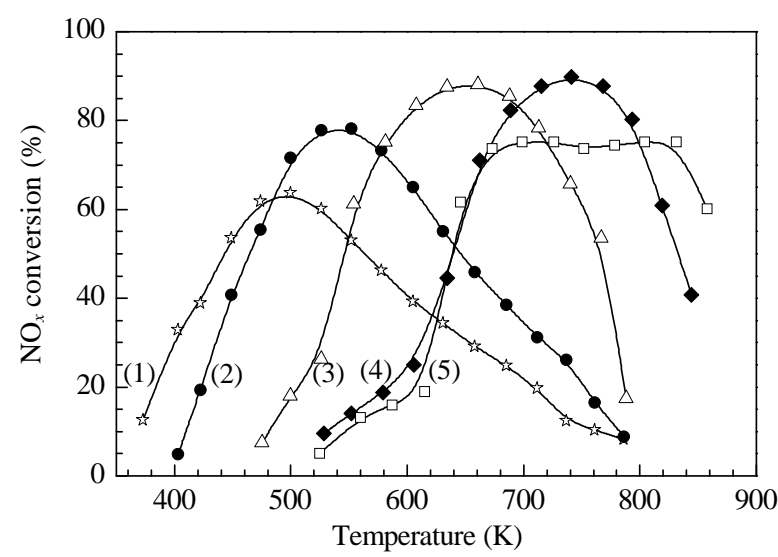

Fig. 3. $\mathrm{NO}_{x}$ conversion over $4 \% \mathrm{Ag} / \mathrm{Al}_{2} \mathrm{O}_{3}$ coupled with Ni-based catalysts supported on different oxides. (1) $5 \% \mathrm{Ni} / \mathrm{La}_{2} \mathrm{O}_{2} \mathrm{CO}_{3}+4 \% \mathrm{Ag} / \mathrm{Al}_{2} \mathrm{O}_{3}$; (2) $5 \% \mathrm{Ni} / \mathrm{CeO}_{2}+4 \% \mathrm{Ag} / \mathrm{Al}_{2} \mathrm{O}_{3}$; (3) $5 \% \mathrm{Ni} / \mathrm{ZrO}_{2}+4 \% \mathrm{Ag} / \mathrm{Al}_{2} \mathrm{O}_{3}$; (4) $5 \%$ $\mathrm{Ni} / \mathrm{Al}_{2} \mathrm{O}_{3}+4 \% \mathrm{Ag} / \mathrm{Al}_{2} \mathrm{O}_{3} ;(5) 4 \% \mathrm{Ag} / \mathrm{Al}_{2} \mathrm{O}_{3}$. Conditions for the reforming reaction: $\mathrm{H}_{2} \mathrm{O} / \mathrm{O}_{2} / \mathrm{C}=2.45 / 0.5 / 1$ (ca. $2.2 \% \mathrm{O}_{2}$ ), $573 \mathrm{~K}$ vaporization, $\mathrm{N}_{2}$ balance, $W / F=0.072(\mathrm{~g} \cdot \mathrm{s}) / \mathrm{ml}, 773 \mathrm{~K}$. Conditions for SCR reaction: $\mathrm{NO}_{x}$ $0.1 \%, 0_{2} 10 \%, \mathrm{~N}_{2}$ balance, $W / F=0.018(\mathrm{~g} \cdot \mathrm{s}) / \mathrm{ml}$.

tributed to its high boiling point, making it prone to accumulation on the catalyst surface at lower temperatures, resulting in decreased activity [16]. As temperature increased $\mathrm{NO}_{x}$ reduction by $n$-dodecane showed a sharp increase at $650 \mathrm{~K}$ and maintained around $78 \%$ conversion over a wide temperature range of 673-823 K. Having achieved catalytic reforming of $n$ - $\mathrm{C}_{12} \mathrm{H}_{26}$ over the Ni-based catalysts on different supports, downstream conversion of $\mathrm{NO}_{x}$ over $\mathrm{Ag} / \mathrm{Al}_{2} \mathrm{O}_{3}$ was investigated. After catalytic reforming of $n-\mathrm{C}_{12} \mathrm{H}_{26}$ over $\mathrm{Ni} / \mathrm{Al}_{2} \mathrm{O}_{3}, \mathrm{NO}_{x}$ conversion over $\mathrm{Ag} / \mathrm{Al}_{2} \mathrm{O}_{3}$ increased to $90 \%$ within a temperature range of $673-800 \mathrm{~K}$. The optimal temperature range of the $\mathrm{Ni} / \mathrm{ZrO}_{2}$ and $\mathrm{Ag} / \mathrm{Al}_{2} \mathrm{O}_{3}$ coupled system for $\mathrm{NO}_{x}$ conversion was $100 \mathrm{~K}$ lower than that of the $n-\mathrm{C}_{12} \mathrm{H}_{26}$-SCR system, giving a highest $\mathrm{NO}_{x}$ conversion of $90 \%$ at $750 \mathrm{~K}$. This dual catalyst system therefore showed improved $\mathrm{NO}_{x}$ purification efficiency in the typical diesel exhaust temperature range of 573-773 $\mathrm{K}$ $\left(\mathrm{NO}_{x}\right.$ conversion > 60\%). Compared to a $\mathrm{Ni} / \mathrm{ZrO}_{2}+\mathrm{Ag} / \mathrm{Al}_{2} \mathrm{O}_{3}$ coupled system, the combination of $\mathrm{Ni} / \mathrm{CeO}_{2}$ with $\mathrm{Ag} / \mathrm{Al}_{2} \mathrm{O}_{3}$ was found to further improve the low-temperature activity for $\mathrm{NO}_{x}$ reduction, with the active temperature range of the catalyst $100 \mathrm{~K}$ lower than the $\mathrm{Ni} / \mathrm{ZrO}_{2}+\mathrm{Ag} / \mathrm{Al}_{2} \mathrm{O}_{3}$ coupled system. $\mathrm{NO}_{x}$ conversion decreased sharply at temperatures above $600 \mathrm{~K}$ (reaching a maximum of $80 \%$ at $550 \mathrm{~K}$ and then decreasing as temperature was increased further). When $\mathrm{Ag} / \mathrm{Al}_{2} \mathrm{O}_{3}$ was coupled with $\mathrm{Ni} / \mathrm{La}_{2} \mathrm{O}_{2} \mathrm{CO}_{3}, \mathrm{NO}_{x}$ conversion at $375-475 \mathrm{~K}$ was $10 \%$ higher than for the $\mathrm{Ni} / \mathrm{CeO}_{2}+\mathrm{Ag} / \mathrm{Al}_{2} \mathrm{O}_{3}$ coupled system, but the highest $\mathrm{NO}_{x}$ conversion observed was lower (60\% at $\left.500 \mathrm{~K}\right)$. Using this dual catalyst system, the decrease in $\mathrm{NO}_{x}$ conversion at temperatures above $500 \mathrm{~K}$ was also pronounced.

The mechanism of the $\mathrm{H}_{2}$ effect in HC-SCR over $\mathrm{Ag} / \mathrm{Al}_{2} \mathrm{O}_{3}$ is still under intense debate, but it has been generally accepted that the presence of $\mathrm{H}_{2}$ promotes partial oxidation of HCs and affects $\mathrm{NO}_{x}$ reduction, particularly at low temperatures $[24,31,44,45]$. The influence of $\mathrm{H}_{2}$ on the activity of $\mathrm{Ag} / \mathrm{Al}_{2} \mathrm{O}_{3}$ catalysts for $\mathrm{NO}_{x}$ reduction has been found to be strongly dependent on the reaction conditions, for example, the concentra-
Table 2

Changes in concentration of species involved in SCR reaction at $650 \mathrm{~K}$.

\begin{tabular}{lccccccc}
\hline \multirow{2}{*}{ Sample } & \multicolumn{2}{c}{$\mathrm{H}_{2}{ }^{\mathrm{a}}(\%)$} & $\mathrm{CO}_{2}$ yield & $\mathrm{b}$ & \multicolumn{2}{c}{$\mathrm{HC} / \mathrm{NO}_{x}$} & \multicolumn{2}{c}{ Conversion (\%) } \\
\cline { 2 - 5 } \cline { 6 - 8 } & Initial & 3 h later & $(\%)$ & in SCR & $\mathrm{HC}$ & $\mathrm{NO}_{x}$ \\
\hline $5 \% \mathrm{Ni} / \mathrm{La}_{2} \mathrm{O}_{2} \mathrm{CO}_{3}$ & 2.74 & 0.98 & 58.5 & 5.0 & 57 & 30 \\
$5 \% \mathrm{Ni} / \mathrm{CeO}_{2}$ & 2.15 & 1.98 & 41.8 & 7.0 & 51 & 52 \\
$5 \% \mathrm{Ni} / \mathrm{ZrO}_{2}$ & 1.12 & 1.02 & 31.5 & 7.5 & 61 & 88 \\
$5 \% \mathrm{Ni} / \mathrm{Al}_{2} \mathrm{O}_{3}$ & 0.03 & - & 10.3 & 10.0 & 40 & 57 \\
\hline
\end{tabular}

a Measured before SCR reaction.

b Percentage of $n$-dodecane completely oxidized into $\mathrm{CO}_{2}$ during $3 \mathrm{~h}$ reforming reaction.

tions of reductant and $\mathrm{H}_{2}$, ratio of $\mathrm{HC} / \mathrm{NO}_{x}$, reaction temperature, space velocity, and so on. Lee et al. [11] investigated the activity of $2 \% \mathrm{Ag} / \mathrm{Al}_{2} \mathrm{O}_{3}$ for $\mathrm{C}_{3} \mathrm{H}_{6} / \mathrm{C}_{8} \mathrm{H}_{18}-\mathrm{SCR}$, during which $\mathrm{NO}_{x}$ conversion significantly improved from $0 \%$ to $64 \%$ at $523 \mathrm{~K}$ with an increase of the $\mathrm{H}_{2} / \mathrm{N}$ ratio from 0 to 10 . The $\mathrm{H}_{2}$ promotion effect was also evaluated on a diesel engine by using a $\mathrm{Ag} / \mathrm{Al}_{2} \mathrm{O}_{3}$-coated monolith catalyst by Sitshebo et al. [37]. At low engine loads $\left(\mathrm{HC} / \mathrm{NO}_{x} \approx 0.9,17 \% \mathrm{O}_{2}, 375 \mathrm{~K}\right)$, $\mathrm{NO}_{x}$ conversion gradually improved with increasing $\mathrm{H}_{2}$ concentration $\left(\mathrm{H}_{2} / \mathrm{N}=0-14\right)$. At higher engine loads $\left(\mathrm{HC} / \mathrm{NO}_{x} \approx 0.5, \mathrm{O}_{2} 10.7 \%\right.$, $535 \mathrm{~K}$ ), complete oxidation of HC occurred only when the $\mathrm{H}_{2} / \mathrm{N}$ ratio was above 2.25 , leading to reduced $\mathrm{NO}_{x}$ conversion. $\mathrm{Re}$ cently, SCR of $\mathrm{C}_{3} \mathrm{H}_{6}$ and $\mathrm{C}_{12} \mathrm{H}_{26}$ assisted by catalytic partial oxidation reforming of $n$ - $\mathrm{C}_{12} \mathrm{H}_{26}$ over a diesel fuel cracking catalyst was performed by Lee et al. [11], in which an optimum ratio $\left(\mathrm{H}_{2} / \mathrm{HC}\right)$ was required for $\mathrm{NO}_{x}$ reduction at low temperatures over $\mathrm{Ag} / \mathrm{Al}_{2} \mathrm{O}_{3}$.

Based on this literature, we also investigated the effect of $\mathrm{H}_{2}$ concentration on $\mathrm{HC} / \mathrm{NO}_{x}$ and $\mathrm{NO}_{x}$ conversion over different coupled systems at $650 \mathrm{~K}$ (Table 2). At the beginning of the reforming reaction over $\mathrm{Ni} / \mathrm{Al}_{2} \mathrm{O}_{3}$, about $10.3 \%$ of the reductant was completely oxidized to $\mathrm{CO}_{2}$, producing $0.03 \% \mathrm{H}_{2}$ and $\mathrm{HCs}$ with a $\mathrm{HC} / \mathrm{NO}_{x}$ ratio of 10 available for further SCR reaction. Over the coupled $\mathrm{Ag} / \mathrm{Al}_{2} \mathrm{O}_{3}$ catalyst system, 57\% $\mathrm{NO}_{x}$ conversion was observed. As for fuel reforming over $\mathrm{Ni} / \mathrm{La}_{2} \mathrm{O}_{2} \mathrm{CO}_{3}$, initial $\mathrm{H}_{2}$ production increased to $2.74 \%$, giving the lowest $\mathrm{HC} / \mathrm{NO}_{x}$ ratio of 5 for SCR reaction and the lowest $\mathrm{NO}_{x}$ conversion of $30 \%$ among the all tested dual catalyst systems. After running for $3 \mathrm{~h}$, the $\mathrm{H}_{2}$ concentration decreased to $0.98 \%$ over $\mathrm{Ni} / \mathrm{La}_{2} \mathrm{O}_{2} \mathrm{CO}_{3}$, indicating a poor durability for fuel reforming. The second-highest $\mathrm{H}_{2}$ concentration (2.15\%) was obtained during the catalytic reforming of $n-\mathrm{C}_{12} \mathrm{H}_{26}$ over $\mathrm{Ni} / \mathrm{CeO}_{2}$, leaving the second-lowest $\mathrm{HC}$ concentration for $\mathrm{NO}_{x}$ reduction and thus the second-lowest $\mathrm{NO}_{x}$ conversion (52\%). Among the tested systems, the $\mathrm{Ni} / \mathrm{ZrO}_{2}+\mathrm{Ag} / \mathrm{Al}_{2} \mathrm{O}_{3}$ coupled system achieved the highest $\mathrm{NO}_{x}$ conversion (around 88\%) at a temperature of 650 $\mathrm{K}$, with a $\mathrm{H}_{2}$ concentration of $1.12 \%$ and a $\mathrm{HC} / \mathrm{NO}_{x}$ ratio of 7.5. The combined results presented in Table 2 and Fig. 2 show that the support employed in the Ni-based catalysts had a remarkable influence on the catalytic reforming performance. As $\mathrm{H}_{2}$ concentration from fuel reforming increased, the coupled SCR catalyst for $\mathrm{NO}_{x}$ reduction gave a higher activity at low temperatures. Conversely, as $\mathrm{H}_{2}$ yield increased and complete oxidation of HC was promoted, HCs became unavailable for subsequent SCR reactions. This feature may have contributed to the decrease in the maximum $\mathrm{NO}_{x}$ conversion achieved on our dual 


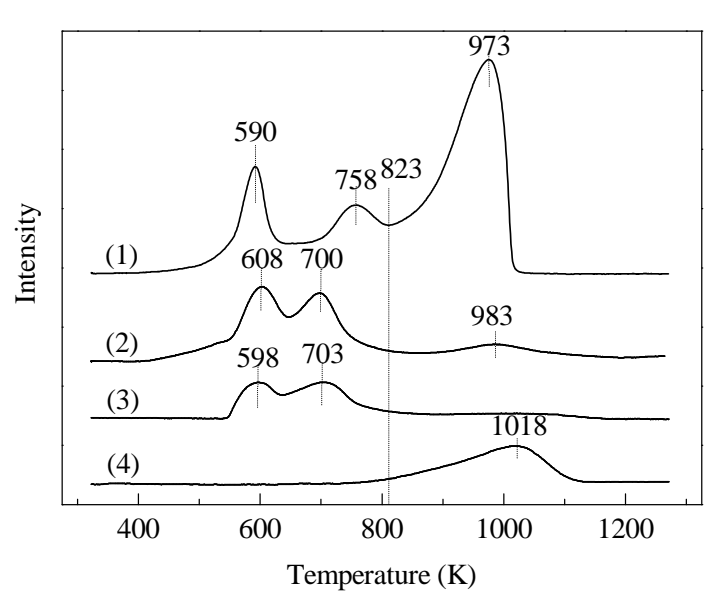

Fig. 4. $\mathrm{H}_{2}$-TPR profiles of the Ni-based catalysts supported on different oxides. (1) $5 \% \mathrm{Ni} / \mathrm{La}_{2} \mathrm{O}_{2} \mathrm{CO}_{3}$; (2) $5 \% \mathrm{Ni} / \mathrm{CeO}_{2}$; (3) $5 \% \mathrm{Ni} / \mathrm{ZrO}_{2}$; (4) $5 \%$ $\mathrm{Ni} / \mathrm{Al}_{2} \mathrm{O}_{3}$.

catalyst systems. After catalytic reforming, a higher $\mathrm{H}_{2}$ yield was commonly accompanied by a lower concentration of HCs, possibly suggesting that complete oxidation of HCs was promoted by excess $\mathrm{H}_{2}$. It is also noteworthy that the HCs in the reforming products were mainly small molecular weight oxygenated HCs with less than 4 carbon atoms according to GC analysis. The small molecular weight oxygenated HCs were likely beneficial for $\mathrm{NO}_{x}$ reduction.

\subsection{Redox performance of reforming catalysts}

Generally, $\mathrm{H}_{2}$ production from catalytic reforming of $\mathrm{HC}$ was closely related to the redox performance of the employed catalyst and interactions between the active component and support [46-48]. To highlight this issue, $\mathrm{H}_{2}$-TPR measurements were carried out on the Ni-based catalysts, with results shown in Fig. 4 and Table 3. Over $\mathrm{Ni} / \mathrm{Al}_{2} \mathrm{O}_{3}$, a strong interaction between $\mathrm{Ni}$ species and the support resulted in the formation of the $\mathrm{NiAl}_{2} \mathrm{O}_{4}$ spinel structure, reduction of which occurred at temperatures above $800 \mathrm{~K}$, exhibiting a wide $\mathrm{H}_{2}$ consumption peak within the range $800-1120 \mathrm{~K}$. During $\mathrm{H}_{2}$ reduction of $\mathrm{Ni} / \mathrm{ZrO}_{2}$, two peaks emerged, centered at 598 and $703 \mathrm{~K}$. The low-temperature peak could be assigned to the reduction of surface-dispersed $\mathrm{NiO}$ particles and the high-temperature peak to reduction of a $\mathrm{NiO}$ species weakly interacting with $\mathrm{ZrO}_{2}$ [49]. The $\mathrm{H}_{2}$ consumption of the above two peaks was $758 \mu \mathrm{mol} / \mathrm{g}$, slightly lower than that required for complete reduction of $\mathrm{NiO}$

\section{Table 3}

Peak temperature and $\mathrm{H}_{2}$ consumption of the Ni-based catalysts supported on different oxides during $\mathrm{H}_{2}$-TPR analysis.

\begin{tabular}{lccccccc}
\hline \multirow{2}{*}{ Sample } & \multicolumn{3}{c}{ Temperature $(\mathrm{K})$} & Ratio $^{\mathrm{b}}$ & \multicolumn{3}{c}{$\mathrm{H}_{2^{\mathrm{a}}}(\mu \mathrm{mol} / \mathrm{g})$} \\
\cline { 2 - 3 } \cline { 6 - 8 } & Peak 1 & Peak 2 & Peak 3 & & (\%) & Peak 1 Peak 2 & Peak 3 \\
\hline $5 \% \mathrm{Ni} / \mathrm{La}_{2} \mathrm{O}_{2} \mathrm{CO}_{3}$ & 590 & 758 & 975 & 94 & 792 & 760 & 2390 \\
$5 \% \mathrm{Ni} / \mathrm{CeO}_{2}$ & 608 & 700 & 983 & 64 & 540 & 475 & 114 \\
$5 \% \mathrm{Ni} / \mathrm{ZrO}_{2}$ & 598 & 703 & - & 27 & 230 & 528 & - \\
$5 \% \mathrm{Ni} / \mathrm{Al}_{2} \mathrm{O}_{3}$ & - & - & 1018 & - & - & - & 905 \\
\hline
\end{tabular}

${ }^{\mathrm{a}} \mathrm{H}_{2}$ consumption corresponding to the reduction peak.

${ }^{b}$ Ratio of $\mathrm{H}_{2}$ consumption of peak 1 to the theoretical value $\left(\mathrm{H}_{2}\right.$ consumption required for complete reduction of $\mathrm{NiO}$ ).
(845 $\mu \mathrm{mol} / \mathrm{g}$, hereafter denoted as the theoretical value), indicating a good dispersion of Ni species, which was confirmed by the XRD analysis. Similarly, two peaks centered at 608 and 700 $\mathrm{K}$ were observed on $\mathrm{Ni} / \mathrm{CeO}_{2}$. The first feature began at $450 \mathrm{~K}$ and was assignable to the reduction of surface adsorbed oxygen on the surface of $\mathrm{CeO}_{2}$ and dispersed $\mathrm{NiO}$ species. The high temperature peak was attributed to the reduction of bulk-like $\mathrm{NiO}$ and the $\mathrm{CeO}_{2}$ interacting with $\mathrm{Ni}$ species [50]. A reduction of bulk $\mathrm{CeO}_{2}$ was also observed for this catalyst at $983 \mathrm{~K}$. Over $\mathrm{Ni} / \mathrm{La}_{2} \mathrm{O}_{2} \mathrm{CO}_{3}$, a strong $\mathrm{H}_{2}$ consumption peak centered at $975 \mathrm{~K}$ was induced by reduction of bulk $\mathrm{La}^{3+}$ [51]. The reduction of the $\mathrm{NiO}$ surface also resulted in a sharp peak at $590 \mathrm{~K}$, the $\mathrm{H}_{2}$ consumption of which was $792 \mu \mathrm{mol} / \mathrm{g}$ and approached theoretical maximum reduction (94\%). Considering that there was only one peak centered at $975 \mathrm{~K}$ in the $\mathrm{H}_{2}$-TPR profile of $\mathrm{La}_{2} \mathrm{O}_{2} \mathrm{CO}_{3}$, the peak at $758 \mathrm{~K}$ observed over $\mathrm{Ni} / \mathrm{La}_{2} \mathrm{O}_{2} \mathrm{CO}_{3}$ may have resulted from reduction of the active components having intimate interaction with the support.

By carefully comparing the $\mathrm{H}_{2}$-TPR results of Ni-based catalysts supported on different oxides, Sato et al. [52] identified that superior redox performance of $\mathrm{Ni} / \mathrm{Ce}_{0.5} \mathrm{Zr}_{0.5} \mathrm{O}_{2}$ was crucial for ethanol reforming at low temperatures. On a molecular level, De Lima et al. [53] revealed the key role of surface oxygen species in guaranteeing the stability of $\mathrm{Pt} / \mathrm{CeZrO}_{2}$ catalyst for oxidative steam reforming of ethanol. As shown in Fig. 4, the reduction temperature peaks of surface-dispersed $\mathrm{NiO}$ (peak 1) over catalysts prepared by the homogeneous precipitation method were centered at similar temperatures (around $600 \mathrm{~K}$ ), but the reduction onset temperature for $\mathrm{Ni} / \mathrm{CeO}_{2}$ and $\mathrm{Ni} / \mathrm{La}_{2} \mathrm{O}_{2} \mathrm{CO}_{3}$ was much lower than that of $\mathrm{Ni} / \mathrm{ZrO}_{2}(450 \mathrm{~K}$ for the former two and $540 \mathrm{~K}$ for the latter), indicating that the former two were more readily reduced at low temperatures. The ratios of the $\mathrm{H}_{2}$ consumption to the theoretical value for peak 1 are listed in Table 3, where ratios of 27\%,64\%, and $94 \%$ were determined for $\mathrm{Ni} / \mathrm{ZrO}_{2}, \mathrm{Ni} / \mathrm{CeO}_{2}$, and $\mathrm{Ni} / \mathrm{La}_{2} \mathrm{O}_{2} \mathrm{CO}_{3}$, respectively. The larger amount of reducible surface $\mathrm{NiO}$ species gave a higher reducibility at low temperatures. As the reducibility of Ni-based catalysts increased at low temperatures, $\mathrm{H}_{2}$ production from fuel reforming was enhanced, and the amount of HCs available for further SCR reactions was reduced (Table 2). Therefore, the temperature range for $\mathrm{NO}_{x}$ removal over the coupled system shifted to lower temperatures at the expense of maximum $\mathrm{NO}_{x}$ conversion efficiency. The results presented above clearly show the critical role of the redox performance of the reforming catalyst in $\mathrm{NO}_{x}$ reduction over the coupled system of reforming-SCR catalysts. With $\mathrm{Ni} / \mathrm{ZrO}_{2}$, having a moderate reducibility, optimal concentrations of $\mathrm{H}_{2}$ and $\mathrm{HCs}$ were determined for the $\mathrm{Ni} / \mathrm{ZrO}_{2}+\mathrm{Ag} / \mathrm{Al}_{2} \mathrm{O}_{3}$ coupled system reforming process giving outstanding $\mathrm{NO}_{x}$ reduction efficiency at typical diesel exhaust temperatures.

\subsection{Catalytic durability}

As can be seen from Table 2, $\mathrm{H}_{2}$ generation from the reforming reaction over $\mathrm{Ni}$-based catalysts decreased by different degrees over time, which was likely related to deposition of carbon on the surface of the catalysts [53]. Therefore, TG anal- 


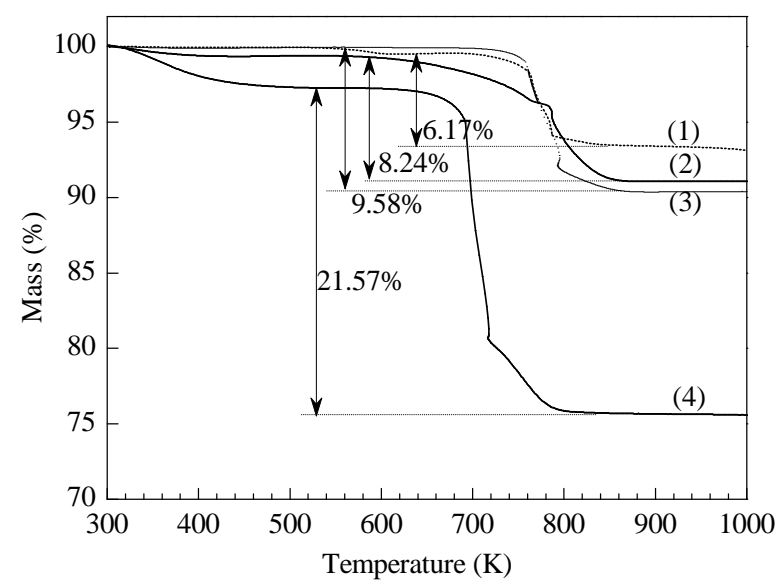

Fig. 5. TG analysis of Ni-based catalysts supported on different oxides after $3 \mathrm{~h}$ operating for $n-\mathrm{C}_{12} \mathrm{H}_{26}$ reforming. (1) $5 \% \mathrm{Ni} / \mathrm{La}_{2} \mathrm{O}_{2} \mathrm{CO}_{3}$; (2) $5 \%$ $\mathrm{Ni} / \mathrm{CeO}_{2}$; (3) $5 \% \mathrm{Ni} / \mathrm{ZrO}_{2}$; (4) $5 \% \mathrm{Ni} / \mathrm{Al}_{2} \mathrm{O}_{3}$.

ysis was conducted on reforming catalysts that had been used for $3 \mathrm{~h}$ at $873 \mathrm{~K}$, with results shown in Fig. 5. A weight loss of $21.57 \%$ was observed from the used $\mathrm{Ni} / \mathrm{Al}_{2} \mathrm{O}_{3}$, indicating considerable carbon deposition. An average rate of carbon deposition of $0.072 \mathrm{~g}$-C/(g-cat.h) over $\mathrm{Ni} / \mathrm{Al}_{2} \mathrm{O}_{3}$ was calculated based on the loss rate per unit time and per unit weight of catalyst. It should be noted that $\mathrm{C}_{2} \mathrm{H}_{4}$ with a relative concentration of about $0.15 \%$ was detected by GC during the reforming of $n-\mathrm{C}_{12} \mathrm{H}_{26}$ over $\mathrm{Ni} / \mathrm{Al}_{2} \mathrm{O}_{3}$, while this compound was not detected from other reforming catalysts. This result further suggested that the strong surface acidity of $\mathrm{Al}_{2} \mathrm{O}_{3}$ contributed to the formation of $\mathrm{C}_{2} \mathrm{H}_{4}$, as a major byproduct during $\mathrm{H}_{2}$ production from the reforming process. The occurrence of $\mathrm{C}_{2} \mathrm{H}_{4}$ is likely linked to the high rate of carbon deposition [46]. The weight loss of Ni-based catalysts supported on $\mathrm{ZrO}_{2}, \mathrm{CeO}_{2}$, and $\mathrm{La}_{2} \mathrm{O}_{2} \mathrm{CO}_{3}$ was considerably less than $\mathrm{Ni} / \mathrm{Al}_{2} \mathrm{O}_{3}$, at $9.58 \%$, $8.24 \%$, and $6.17 \%$, respectively. Clearly, the redox performance of the reforming catalyst not only affected the yield of $\mathrm{H}_{2}$ but also contributed to its durability in the reforming process. Higher redox performance for the reforming catalyst inhibited carbon deposition and guaranteed longer lifetimes, which is in accordance with previous reports $[47,48]$. In addition, the reaction of $\mathrm{La}_{2} \mathrm{O}_{2} \mathrm{CO}_{3}+\mathrm{C} \rightarrow \mathrm{La}_{2} \mathrm{O}_{3}+2 \mathrm{CO}$ occurred during reforming of $n-\mathrm{C}_{12} \mathrm{H}_{26}$ over $\mathrm{Ni} / \mathrm{La}_{2} \mathrm{O}_{2} \mathrm{CO}_{3}$, which may further reduce carbon deposition [51].

With consideration of the excellent $\mathrm{NO}_{x}$ removal efficiency of the $\mathrm{Ni} / \mathrm{ZrO}_{2}+\mathrm{Ag} / \mathrm{Al}_{2} \mathrm{O}_{3}$ system, time dependence of $\mathrm{H}_{2}$ production at $773 \mathrm{~K}$ and $\mathrm{NO}_{x}$ conversion at $650 \mathrm{~K}$ were measured using this system (Fig. 6). During the first $2 \mathrm{~h}$, there was a slight drop in $\mathrm{H}_{2}$ concentration, which may have contributed to a decrease in $\mathrm{NO}_{x}$ conversion. In the following $3 \mathrm{~h}, \mathrm{H}_{2}$ concentration remained at a level of about $1 \%$, and $\mathrm{NO}_{x}$ conversion remained relatively stable (around 88\%). As reaction continued, the $\mathrm{H}_{2}$ concentration showed a sharp drop to around $0.2 \%$ after $10 \mathrm{~h}$, followed by a slow decrease over the next $14 \mathrm{~h}$. The lower $\mathrm{H}_{2}$ concentration led to a corresponding decline in $\mathrm{NO}_{x}$ conversion although the rate of decline of $\mathrm{NO}_{x}$ conversion was much slower than decrease in that of $\mathrm{H}_{2}$ concentration. As a result, $\mathrm{NO}_{x}$ conversion was maintained at $70 \%$ even after running for

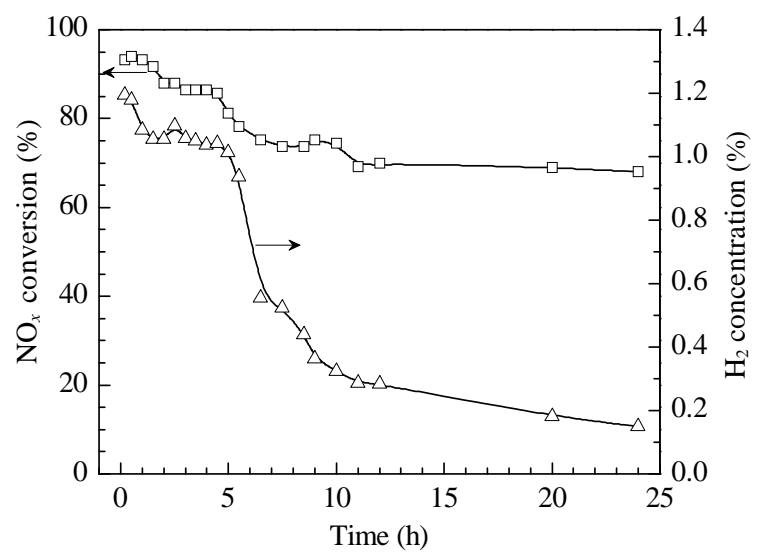

Fig. 6. Time dependence of $\mathrm{NO}_{x}$ conversion and $\mathrm{H}_{2}$ concentration (measured before SCR reaction) during the $n-\mathrm{C}_{12} \mathrm{H}_{26}$ reforming-SCR over the $\mathrm{Ni} / \mathrm{ZrO}_{2}+\mathrm{Ag} / \mathrm{Al}_{2} \mathrm{O}_{3}$ coupled system. Conditions for reforming reaction: $\mathrm{H}_{2} \mathrm{O} / \mathrm{O}_{2} / \mathrm{C}=2.45 / 0.5 / 1$ (ca. $2.2 \% \mathrm{O}_{2}$ ), $573 \mathrm{~K}$ vaporization, $\mathrm{N}_{2}$ balance, $W / F=0.072(\mathrm{~g} \cdot \mathrm{s}) / \mathrm{ml}, 773 \mathrm{~K}$. Conditions for SCR reaction: NO $0.1 \%, \mathrm{O}_{2} 10 \%, \mathrm{~N}_{2}$ balance, $W / F=0.018(\mathrm{~g} \cdot \mathrm{s}) / \mathrm{ml}, 650 \mathrm{~K}$.

$24 \mathrm{~h}$. During TG analysis of the $\mathrm{Ni} / \mathrm{ZrO}_{2}$ sample from $24 \mathrm{~h}$ of operation, a weight loss of $16.5 \%$ was observed within the temperature range of 573-873 K. This provided evidence of carbon deposition and suggested an area for further improvement.

\section{Conclusions}

The redox performance of Ni-based catalysts strongly depends on the nature of the support used in the catalyst preparation. The choice of support may affect the concentrations of $\mathrm{H}_{2}$ and HCs with small molecular weight that form during the catalytic reforming of $n-\mathrm{C}_{12} \mathrm{H}_{26}$. This in turn affects the $\mathrm{NO}_{x}$ conversion over the fuel reforming-SCR coupled system. An optimal concentration ratio of $\mathrm{H}_{2}$ to low $\mathrm{HCs}$ could be found for some systems (e.g., $\mathrm{H}_{2} 1.1 \%, \mathrm{HC} / \mathrm{NO}_{x}=7.5$ during fuel reforming over $\mathrm{Ni} / \mathrm{ZrO}_{2}$ ). A coupled system of $\mathrm{Ni} / \mathrm{ZrO}_{2}+\mathrm{Ag} / \mathrm{Al}_{2} \mathrm{O}_{3}$ demonstrated high efficiency for $\mathrm{NO}_{x}$ conversion at typical diesel exhaust temperatures. Carbon deposition over Ni-based catalysts induced a decrease in $\mathrm{H}_{2}$ production and thus lowered $\mathrm{NO}_{x}$ conversion from the fuel reforming-SCR coupling system.

\section{References}

[1] He H, Yu Y B, Li Y, Wu Q Zhang X L, Zhang C B, Shi X Y, Song X P. Chin J Catal (贺泓, 余运波, 李毅, 吴强, 张秀丽, 张长斌, 石晓燕, 宋小萍. 催化学报), 2010, 31: 491

[2] Shelef M. Chem Rev, 1995, 95: 209

[3] Li J H, Hao J M, Fu L X, Zhu T L, Liu Z M, Cui X Y. Appl Catal A, 2004, 265: 43

[4] Liu Z M, Ihl Woo S. Catal Rev-Sci Eng, 2006, 48: 43

[5] Wang X P, Yang H L, Yu Q, Zhang S X. Catal Lett, 2007, 113: 109

[6] Zhao Zh, Zhang G Zh, Liu J, Liang P, Xu J, Duan A J, Jiang G Y, Xu Ch M. Chin J Catal (赵震, 张桂臻, 刘坚, 梁鹏, 许洁, 段爱军, 姜桂元, 徐春明. 催化学报), 2008, 29: 303

[7] Mriyadera T. Appl Catal B, 1993, 2: 199

[8] Shimizu K, Satsuma A, Hattori T. Appl Catal B, 2000, 25: 239

[9] Shimizu K, Shibata J, Yoshida H, Satsuma A, Hattori T. Appl Catal B, 2001, 30: 151 


\title{
Graphical Abstract
}

Chin. J. Catal., 2013, 34: 1407-1417 doi: 10.1016/S1872-2067(12)60598-1

Fuel reforming over Ni-based catalysts coupled with selective catalytic reduction of $\mathrm{NO}_{x}$

ZHAO Jiaojiao, YU Yunbo*, HAN Xue, HE Hong

Research Center for Eco-Environmental Sciences, Chinese Academy of Sciences

Small molecular weight hydrocarbons and $\mathrm{H}_{2}$ produced from on-board fuel reforming over Ni-based catalysts were used as reductants in the selective catalytic reduction of $\mathrm{NO}_{x}$ over $\mathrm{Ag} / \mathrm{Al}_{2} \mathrm{O}_{3}$ catalysts at typical diesel exhaust temperatures.

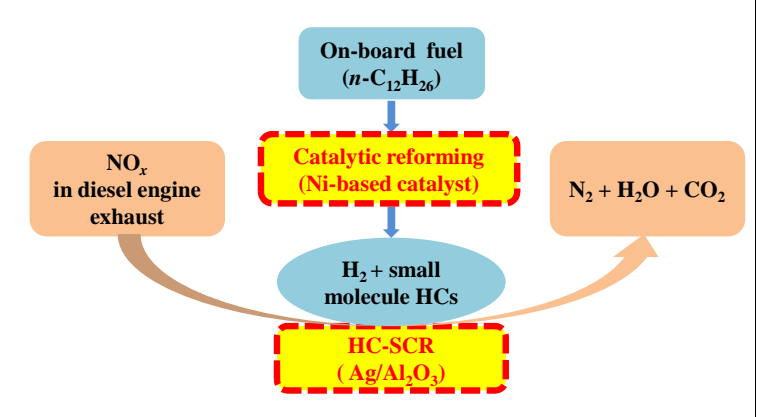

[10] Houel V, Millington P, Rajaram R, Tsolakis A. Appl Catal B, 2007, 73: 203

[11] Lee J, Song S, Chun K M. Ind Eng Chem Res, 2010, 49: 3553

[12] Yu Y B, He H. Chin J Catal (余运波, 贺泓. 催化学报), 2003, 24: 385

[13] Shimizu K, Shibata J, Satsuma A, Hattori T. Phys Chem Chem Phys, 2001, 3: 880

[14] Eränen K, Lindfors L-E, Klingstedt F, Murzin D Y. J Catal, 2003, 219: 25

[15] Yoon D Y, Park J H, Kang H C, Kim P S, Nam I S, Yeo G K, Kil J K, Cha M S. Appl Catal B, 2011, 101: 275

[16] Hernández Carucci J R, Arve K, Bártová Š, Eränen K, Salmi T, Murzin D Y. Catal Sci Technol, 2011, 1: 1456

[17] He H, Zhang C B, Yu Y B. Catal Today, 2004, 90: 191

[18] Yu Y B, He H, Feng Q C, Gao H W, Yang X. Appl Catal B, 2004, 49: 159

[19] He H, Yu Y B. Catal Today, 2005, 100: 37

[20] Nakatsuji T, Yasukawa R, Tabata K, Ueda K, Niwa M. Appl Catal B, 1998, 17: 333

[21] Burch R, Coleman M D. Appl Catal B, 1999, 23: 115

[22] Eränen K, Klingstedt F, Arve K, Lindfors L-E, Murzin D Y. J Catal, 2004, 227: 328

[23] Burch R, Breen J P, Hill C J, Krutzsch B, Konrad B, Jobson E, Cider L, Eränen K, Klingstedt F, Lindfors L-E. Top Catal, 2004, 30/31: 19

[24] Satokawa S, Shibata J, Shimizu K, Satsuma A, Hattori T, Kojima T. Chem Eng Sci, 2007, 62: 5335

[25] Satokawa S. Chem Lett, 2000, 29: 294

[26] Breen J P, Burch R. Top Catal, 2006, 39: 53

[27] Arve K, Backman H, Klingstedt F, Eränen K, Murzin D Y. Appl Catal B, 2007, 70: 65

[28] Da Silva R, Cataluña R, Martínez-Arias A. Catal Today, 2009, 143: 242

[29] Houel V, Millington P, Rajaram R, Tsolakis A. Appl Catal B, 2007, 77: 29

[30] DiMaggio C L, Fisher G B, Rahmoeller K M, Sellnau M. SAE Int J Fuels Lubr, 2009, 2: 66

[31] Zhang X L, Yu Y B, He H. Appl Catal B, 2007, 76: 241

[32] Moon D J. Catal Surv Asia, 2011, 15: 25
[33] Bromberg L, Rabinovich A, Alexeev N, Cohn D R. Cambridge: Plasma Science and Fusion Center, Massachusetts Institute of Technology, 1999. PSFC/JA-99-4

[34] Li Y D, Chen J L, Qin Y N, Chang L. Energ Fuel, 2000, 14: 1188

[35] Chen H Q, Yu H, Peng F, Wang H J, Yang J, Pan M Q. J Catal, 2010, 269: 281

[36] Cai W J, Wang F G, Zhan E S, Van Veen A C, Mirodatos C, Shen W J. J Catal, 2008, 257: 96

[37] Sitshebo S, Tsolakis A, Theinnoi K. Int J Hydrogen Energy, 2009, 34: 7842

[38] Liu H M, He D H. Catal Surv Asia, 2012, 16: 53

[39] Wang F G, Li Y, Cai W J, Zhan E S, Mu X N, Shen W J. Catal Today, 2009, 146: 31

[40] Seyedeyn Azad F, Abedi J, Salehi E, Harding T. Chem Eng J, 2012, 180: 145

[41] Li S R, Li M S, Zhang C X, Wang S P, Ma X B, Gong J L. Int J Hydrogen Energy, 2012, 37: 2940

[42] Gould B D, Chen X, Schwank J W. J Catal, 2007, 250: 209

[43] Shan W P, Liu F D, He H, Shi X Y, Zhang C B. Appl Catal B, 2012, 115-116: 100

[44] Sazama P, Čapek L, Drobná H, Sobalík Z, Dědeček J, Arve K, Wichterlová B. J Catal, 2005, 232: 302

[45] Creaser D, Kannisto H, Sjöblom J, Ingelsten H H. Appl Catal B, 2009, 90: 18

[46] Youn M H, Seo J G, Cho K M, Jung J C, Kim H, La K W, Park D R, Park S, Lee S H, Song I K. Korean J Chem Eng, 2008, 25: 236

[47] Roh H S, Jun K W, Dong W S, Chang J S, Park S E, Joe Y I. J Mol Catal A, 2002, 181: 137

[48] Wang H Y, Ruckenstein E. Appl Catal A, 2000, 204: 143

[49] García V, Fernández J J, Ruíz W, Mondragón F, Moreno A. Catal Commun, 2009, 11: 240

[50] Kugai J, Velu S, Song C. Catal Lett, 2005, 101: 255

[51] Shi Q J, Li B, Chen W Q, Liu C W, Huang B W. Adv Mater Res, 2012, 457-458: 314

[52] Sato K, Kawano K, Ito A, Takita Y, Nagaoka K. ChemSusChem, 2010, 3: 1364

[53] De Lima S M, Da Cruz I O, Jacobs G, Davis B H, Mattos L V, Noronha F B. J Catal, 2008, 257: 356

\section{$\mathrm{Ni}$ 基催化剂催化燃油重整耦合选择性催化还原 $\mathrm{NO}_{x}$ 反应}

\author{
赵娇娇, 余运波 ${ }^{*}$, 韩雪, 贺泓 \\ 中国科学院生态环境研究中心, 北京100085
}


摘要: 分别以 $\mathrm{La}_{2} \mathrm{O}_{2} \mathrm{CO}_{3}, \mathrm{CeO}_{2}, \mathrm{ZrO}_{2}$ 和 $\mathrm{Al}_{2} \mathrm{O}_{3}$ 为载体, 采用浸渍法制备了 $\mathrm{Ni}$ 基重整催化剂, 并以正十二烷模拟车载燃油进行催化重 整反应以同时制备小分子碳氢化合物( $\mathrm{HCs})$ 和 $\mathrm{H}_{2}$, 考察了其在 $4 \mathrm{wt} \% \mathrm{Ag} / \mathrm{Al}_{2} \mathrm{O}_{3}$ 上选择性催化还原( $\left.\mathrm{HC}-\mathrm{SCR}\right)$ 氮氧化物 $\left(\mathrm{NO}_{x}\right)$ 的性能. 采用 $\mathrm{N}_{2}$ 吸附-脱附、X射线粉末衍射、 $\mathrm{H}_{2}$ 程序升温还原和热重等手段对 $\mathrm{Ni}$ 基催化剂进行了表征. 结果表明, 随着重整催化剂氧化 还原性能增强, 产物中 $\mathrm{H}_{2}$ 浓度增加, 可参与SCR反应的HCs含量减少, 从而导致重整-SCR耦合体系上 $\mathrm{NO}_{x}$ 净化活性温度窗口向低 温移动, $\mathrm{NO}_{x}$ 最高转化率降低. $\mathrm{Ni} / \mathrm{ZrO}_{2}+\mathrm{Ag} / \mathrm{Al}_{2} \mathrm{O}_{3}$ 耦合体系中 $\mathrm{H}_{2} / \mathrm{HCs}$ 符合 $\mathrm{SCR}$ 反应所需的最优比例, 在柴油车典型排气温度范围 内表现出良好的 $\mathrm{NO}_{x}$ 净化能力. 同时, 在 $\mathrm{Ni} / \mathrm{ZrO}_{2}+\mathrm{Ag} / \mathrm{Al}_{2} \mathrm{O}_{3}$ 耦合体系上考察了其燃油重整-SCR的活性稳定性. 结果显示, 重整催 化剂的耐久性有待进一步提高.

关键词：燃油重整; 镍基催化剂; 氮氧化物; 选择性催化还原; 银; 氧化铝

收稿日期: 2013-02-07. 接受日期: 2013-04-02. 出版日期: 2013-07-20.

*通讯联系人. 电话/传真: (010)62849121; 电子信箱: ybyu@rcees.ac.cn

基金来源：国家自然科学基金(21177142); 国家重点基础研究发展计划(973计划, 2010CB732304); 国家高技术研究发展计划(863 计划, 2013AA065301).

本文的英文电子版由Elsevier出版社在ScienceDirect上出版(http://www.sciencedirect.com/science/journal/18722067).

\section{1. 前言}

柴油机以其优良的动力性与经济性成为未来机动 车发展的主流方向之一, 然而尾气中氮氧化物 $\left(\mathrm{NO}_{x}\right)$ 的净 化是其进一步推广应用的一大瓶颈. 柴油机的稀燃特性 导致三效催化剂不能有效发挥作用 ${ }^{[1]}$, 在这种 $\mathrm{O}_{2}$ 过量的 条件下,选择性还原技术(SCR)表现出较高的 $\mathrm{NO}_{x}$ 净化效 率. 在欧洲、美国、日本等国以尿素为还原剂的Urea/ $\mathrm{NH}_{3}$-SCR技术已商业化应用于柴油车尾气 $\mathrm{NO}_{x}$ 排放控 制, 但该技术仍存在尾气后处理系统复杂、尿素添加站 建设投资大、氨泄漏引发二次污染等缺陷 ${ }^{[2]}$. 以车载燃 油为还原剂来源的碳氢化合物选择性催化还原 $\mathrm{NO}_{x}$ 技术 (HC-SCR) 则可以有效地避免以上问题, 引起了研究者的 广泛关注.

研究表明 ${ }^{[2 \sim 6]}$, 分子篮、碱金属/氧化物和贵金属等催 化剂具备催化 $\mathrm{HC}$ 选择性还原 $\mathrm{NO}_{x}$ 的能力. 其中, 银/氧化 铝 $\left(\mathrm{Ag} / \mathrm{Al}_{2} \mathrm{O}_{3}\right)$ 催化剂表现出优异的 $\mathrm{NO}_{x}$ 净化活性及应用 前景 ${ }^{[1,7 ~ 9]}$. HC-SCR技术净化 $\mathrm{NO}_{x}$ 的效率不仅与催化剂的 性能密切相关, 同时与所选用还原剂的结构及用量相 关 ${ }^{[8 \sim 12]}$. 一般来说, $\mathrm{Ag} / \mathrm{Al}_{2} \mathrm{O}_{3}$ 催化不同结构还原剂选择 性催化还原 $\mathrm{NO}_{x}$ 的活性顺序为: 含氧烃类(醇、醛、酮等)> 直链烃类 $>$ 支链烃类 $>$ 环状烃类. 对直链烷烃还原剂而 言, SCR反应起燃温度随链长的增加而降低: 链长由 $\mathrm{C}_{1}$ 增加至 $\mathrm{C}_{8}$ 时, $2 \% \mathrm{Ag} / \mathrm{Al}_{2} \mathrm{O}_{3}$ 催化净化 $\mathrm{NO}_{x}$ 的起燃温度由 $675 \mathrm{~K}$ 降至 $525 \mathrm{~K}^{[8]}$. $\mathrm{NO}_{x}$ 还原反应速率随直链烷烃碳链 增长而增加 ${ }^{[13]}$, 但 $\mathrm{NO}_{x}$ 最高去除效率降低. Eränen等 ${ }^{[14]}$ 在 $\mathrm{HC} / \mathrm{NO}_{x}=6, \mathrm{GHSV}=60000 \mathrm{~h}^{-1}$ 条件下考察了 $2 \% \mathrm{Ag} /$ $\mathrm{Al}_{2} \mathrm{O}_{3}$ 上 $\mathrm{C}_{8} \mathrm{H}_{18}-\mathrm{SCR}$ 的反应活性, 在 720 770 $\mathrm{K} \mathrm{NO}_{x}$ 最高 转化率可达 $90 \%$. Yoon等 ${ }^{[15]}$ 考察了 $2 \% \mathrm{Ag} / \mathrm{Al}_{2} \mathrm{O}_{3}$ 催化正 十二烷选择性还原 $\mathrm{NO}_{x}$ 的活性, 发现 $\mathrm{NO}_{x}$ 最高转化率约 为 $75 \%\left(G H S V=30000 h^{-1}\right)$. 而直接以 $n-\mathrm{C}_{16} \mathrm{H}_{34}$ 或柴油作
为还原剂时, 在 $1.9 \% \mathrm{Ag} / \mathrm{Al}_{2} \mathrm{O}_{3}$ 上 $\mathrm{NO}_{x}$ 的最高转化率仅为 $50 \%\left(\mathrm{HC} / \mathrm{NO}_{x}=6, \mathrm{GHSV}=60000 \mathrm{~h}^{-1}\right)^{[16]}$. 以柴油如 GTL (Gas-to-Liquid, 含 $0.3 \mathrm{wt} \%$ 芳香烃, S含量可忽略)或US06 (超低S含量, $24 \mathrm{wt} \%$ 芳香烃)等作为还原剂时, $\mathrm{Ag} / \mathrm{Al}_{2} \mathrm{O}_{3}$ 催化剂容易积碳并在很短时间内迅速失活(甚至未能达 到稳态 $)^{[10]}$. 与此相反, 以 $\mathrm{C}_{3} \mathrm{H}_{6}$ 等小分子碳氢化合物为还 原剂时, 在较宽的温度区间内 (700 850 K), 4\% Ag/ $\mathrm{Al}_{2} \mathrm{O}_{3}$ 催化剂上 $\mathrm{NO}_{x}$ 转化率达 $90 \%$ 以上 ${ }^{[17]}$. 以 $\mathrm{C}_{2} \mathrm{H}_{5} \mathrm{OH}$ 或 $\mathrm{CH}_{3} \mathrm{CHO}$ 等为还原剂时, $5 \% \mathrm{Ag} / \mathrm{Al}_{2} \mathrm{O}_{3}$ 上 $\mathrm{NO}_{x}$ 转化率在 $600 \sim 700 \mathrm{~K}$ 范围内高达 $100 \%{ }^{[18]}$; 发动台架试验进一步表 明, $\mathrm{Ag} / \mathrm{Al}_{2} \mathrm{O}_{3}-\mathrm{C}_{2} \mathrm{H}_{5} \mathrm{OH}$ 的组合体系具备了较优异的 $\mathrm{NO}_{x}$ 净 化效率与耐久性 ${ }^{[19]}$. Nakatsuji等 ${ }^{[20]}$ 以柴油作为还原剂来 源, 对比了柴油直接为还原剂或经部分氧化后对 $\mathrm{AgAlO}_{2} / \mathrm{Al}_{2} \mathrm{O}_{3}$ 催化 $\mathrm{NO}_{x}$ 净化性能的影响, 结果显示, 柴油 部分氧化产物(乙醛等含氧小分子)在HC-SCR反应中具 有更高的反应活性. 综上所述, 小分子HCs及含氧HCs 是 $\mathrm{Ag} / \mathrm{Al}_{2} \mathrm{O}_{3}$ 净化 $\mathrm{NO}_{x}$ 的优选还原剂.

$\mathrm{H}_{2}$ 在贵金属催化的SCR反应中表现出优异的低温 活性 ${ }^{[21]}$. 但是, 以 $\mathrm{Ag} / \mathrm{Al}_{2} \mathrm{O}_{3}$ 为催化剂时 $\mathrm{H}_{2}$ 并不是有效的 还原剂 ${ }^{[2224]}$. Satokawa ${ }^{[25]}$ 发现, 少量 $\mathrm{H}_{2}$ 的存在能显著提 高 $\mathrm{Ag} / \mathrm{Al}_{2} \mathrm{O}_{3}$ 催化 $\mathrm{C}_{3} \mathrm{H}_{8}$ 选择性还原 $\mathrm{NO}_{x}$ 的低温活性. 随后, HC-SCR 反应中的 $\mathrm{H}_{2}$ 效应广受关注. 研究表明 ${ }^{[26 ~ 30], ~}$ HC-SCR反应中 $\mathrm{H}_{2}$ 的作用与催化剂类型、还原剂种类及 $\mathrm{H}_{2}$ 添加量密切相关. Zhang等 ${ }^{[31]}$ 的研究显示, 在GHSV = $50000 \mathrm{~h}^{-1}, \mathrm{C} / \mathrm{N}=6$ 条件下, $1 \% \mathrm{H}_{2}$ 的添加有效促进了 $4 \%$ $\mathrm{Ag} / \mathrm{Al}_{2} \mathrm{O}_{3}$ 上 $\mathrm{C}_{3} \mathrm{H}_{6}-\mathrm{SCR}$ 反应的低温活性, 将 $\mathrm{NO}_{x}$ 还原温度 窗口向低温拓宽了 $150 \mathrm{~K}$, 并在 $500 \sim 800 \mathrm{~K}$ 实现 $\mathrm{NO}_{x}$ 转化 $80 \%$ 以上. 为应对 $\mathrm{H}_{2}$ 储存和运输过程中存在的困难和潜 在问题, 众多国内外学者致力于燃油催化重整或等离子 体重整原位制备 $\mathrm{H}_{2}$ 的研究 ${ }^{[32 ~ 36]}$, 为车载电池供给燃料 或为基于HC-SCR反应的 $\mathrm{NO}_{x}$ 净化后处理提供助剂 ${ }^{[11,37]}$. 
在催化重整反应中, $\mathrm{Ni}$ 因其强催化C-C键断裂能力和便 宜易得而备受关注 ${ }^{[38,39]}$. 同时, $\mathrm{Ni}$ 基催化剂的重整性能 如重整产物分布、催化剂耐久性等与载体性质密切相 关 $^{[40 \sim 42]}$, 这为本文重整柴油组分同时制备 $\mathrm{H}_{2}$ 及高活性 HCs小分子提供了可能.

基于以上研究, 本文选用正十二烷作为车载柴油模 拟组分, 以镍基催化剂催化正十二烷重整同时制备小分 子 $\mathrm{HCs}$ 和 $\mathrm{H}_{2}$, 并与高效HC-SCR催化剂 $4 \mathrm{wt} \% \mathrm{Ag} / \mathrm{Al}_{2} \mathrm{O}_{3}$ 耦 合, 在实验室模拟气氛条件下考察了不同氧化物负载的 重整催化剂对耦合体系净化 $\mathrm{NO}_{x}$ 性能的影响.

\section{2. 实验部分}

\section{1. 催化剂的制备}

分别以 $\mathrm{La}, \mathrm{Ce}$ 和Zr的硝酸盐为前驱体, 尿素为沉淀 剂, 采用均匀沉淀法 ${ }^{[43]}$ 制备 La, Ce和Zr的氧化物, $373 \mathrm{~K}$ 烘箱中过夜干燥, 空气气氛中 $873 \mathrm{~K}$ 焙烧 $5 \mathrm{~h}$ 后作为载体 备用. 以上述氧化物及市售拟薄水铝石为载体(或载体 前驱体), 采用浸渍法制备5 wt\%的 $\mathrm{Ni}$ 基重整催化剂, 具 体步骤如下: 将所需量的载体(如 $5 \mathrm{~g}$ ) 加入 $\mathrm{Ni}\left(\mathrm{NO}_{3}\right)_{2}$ 溶液 (50ml, $0.085 \mathrm{~mol} / \mathrm{L})$ 中, 室温搅拌 $1 \mathrm{~h}$, 于 $333 \mathrm{~K}$ 下真空旋 蒸, $373 \mathrm{~K}$ 过夜干燥, 空气气氛中 $873 \mathrm{~K}$ 焙烧 $3 \mathrm{~h}$, 粉碎, 过 篮备用(20 40目).

参照文献[12]方法制备 $4 \mathrm{wt} \% \mathrm{Ag} / \mathrm{Al}_{2} \mathrm{O}_{3}$ 催化剂. 以 上实验药品均购自国药集团试剂有限公司, 分析纯.

\section{2. 催化剂的表征}

X射线粉末衍射(XRD)表征在荷兰PANalytical公司 的 X'Pert Pro型X射线衍射仪上进行, $\mathrm{Cu} K_{\alpha}$ 射线 $(\lambda=$ $0.154056 \mathrm{~nm})$, 扫描范围 $2 \theta=10^{\circ} \sim 90^{\circ}$, 扫描速度 $4^{\circ} / \mathrm{min}$. 样品的比表面积、平均孔径和总孔体积采用美国康塔公 司的Quantasorb-18全自动比表面分析仪测定. 测试之 前, 样品在 $573 \mathrm{~K}$ 脱气处理 $4 \mathrm{~h}$, 然后在 $77 \mathrm{~K}$ 下进行 $\mathrm{N}_{2}$ 吸 附-脱附等温线的测定. 程序升温还原 $\left(\mathrm{H}_{2}-\mathrm{TPR}\right)$ 表征在 美国麦克仪器公司的AutoChem II 2920型吸附仪上进行, 催化剂装量 $100 \mathrm{mg}$, 反应气氛为 $10 \% \mathrm{H}_{2}-90 \% \mathrm{Ar}$, 测试 温度为323 1273 K, 升温速率 $10 \mathrm{~K} / \mathrm{min}$. 反应后样品的 热重 (TG) 分析在 Mrttler Toledo 公司的 TGA/DSC $1\left(\mathrm{STAR}^{\mathrm{e}}\right.$ System)上进行, 反应气氛为 $\mathrm{O}_{2}(50 \mathrm{ml} / \mathrm{min})$, 测 试温度为300 1000 K, 升温速率 $20 \mathrm{~K} / \mathrm{min}$.

\section{3. 催化剂的评价}

以正十二烷 $\left(n-\mathrm{C}_{12} \mathrm{H}_{26}\right.$, 分析纯, $99.8 \%$, 天津福晨化 学试剂有限公司)模拟车载燃油进行重整反应. 催化剂 活性评价在计算机控制的固定床连续评价装置上进行.
反应装置包括两个管式反应炉, 其一为两段式加热炉用 于液态反应物的蒸发和重整反应, 另一用于 SCR反应. 重整反应区液态反应物 $n-\mathrm{C}_{12} \mathrm{H}_{26}$ 和 $\mathrm{H}_{2} \mathrm{O}$ 用微型注射洜 (HARVARD, PHD 2000 Infusion)精确控制添加, 注入速 率分别为 $13 \mu \mathrm{l} / \mathrm{min}$ 和 $30 \mu \mathrm{l} / \mathrm{min}$, 经 $573 \mathrm{~K}$ 管式炉汽化后以 $\mathrm{N}_{2}$ 为载气吹扫进入重整反应炉. 重整反应条件为: $\mathrm{H}_{2} \mathrm{O} / \mathrm{O}_{2} / \mathrm{C}=2.45 / 0.5 / 1$ (约 2.2\% $\mathrm{O}_{2}$ ), $\mathrm{N}_{2}$ 平衡气, $W / F=$ $0.072(\mathrm{~g} \cdot \mathrm{s}) / \mathrm{ml}$, 反应温度 $773 \mathrm{~K}$. 重整产物经过 $273 \mathrm{~K}$ 循 环冷凝设备后通入SCR反应炉. SCR反应条件为: $0.1 \%$ $\mathrm{NO}_{x}, 10 \% \mathrm{O}_{2}, \mathrm{~N}_{2}$ 平衡气, $\mathrm{W} / \mathrm{F}=0.018(\mathrm{~g} \cdot \mathrm{s}) / \mathrm{ml}$, 总气体流 量 $1000 \mathrm{ml} / \mathrm{min}$. $\mathrm{NO}$ 与 $\mathrm{NO}_{2}$ 的浓度采用配备气体池的傅 里叶变换红外光谱仪(Nicolet is10, $0.2 \mathrm{dm}^{3}$ 气体池, 393 $\mathrm{K}$ )检测, 每个测试点达预设温度 $35 \mathrm{~min}$ 后采集数据; $\mathrm{SCR}$ 反应前后 $\mathrm{H}_{2}, \mathrm{CO}_{2}$ 及 $\mathrm{HC}$ 总浓度采用气相色谱仪 (Shimadzu公司, GC-2014C型, 配备2个TCD检测器, 1 个 FID 检测 器) 检测. $\mathrm{O}_{2}, \mathrm{~N}_{2}, \mathrm{CO}_{2}$ 和 $\mathrm{C}_{2} \mathrm{H}_{4}$ 经 Porpack-N柱 $(80 \sim 100$ 目, $3.2 \mathrm{~mm} \times 2.1 \mathrm{~mm} \times 1.0 \mathrm{~m})$ 分离, 由 TCD1 检 测; $\mathrm{H}_{2}$ 经MS-13X分子篎柱(80 100目, $3.2 \mathrm{~mm} \times 2.1 \mathrm{~mm}$ $\times 2.0 \mathrm{~m}$ )分离并由 TCD2检测; 含氧 $\mathrm{HC}$ 如 $\mathrm{CH}_{3} \mathrm{CH}_{2} \mathrm{OH}$ 和 $\mathrm{CH}_{3} \mathrm{COCH}_{3}$ 等经 Rtx-Wax 毛细管柱 $(0.53 \mathrm{~mm} \times 1 \mu \mathrm{m} \times 30$ $\mathrm{m}$ )分离后由FID检测. 耦合反应的简易流程如图1所示.

\section{3. 结果与讨论}

\section{1. 重整催化剂结构性质}

图2为不同载体负载的重整催化剂样品的XRD谱 图. 由此可见, 以拟薄水铝石为前驱体负载 $\mathrm{Ni}$ 后焙烧获 得的样品为 $\mathrm{NiAl}_{2} \mathrm{O}_{4}$ (JCPDS 10-0339) 与 $\mathrm{Al}_{2} \mathrm{O}_{3}$ (JCPDS 74-2206)的复合相; 均匀沉淀法制备的载体分别为六方 结构的 $\mathrm{La}_{2} \mathrm{O}_{2} \mathrm{CO}_{3}$ (JCPDS 84-1963)、方铈矿结构的 $\mathrm{CeO}_{2}$ (JCPDS 43-1002), 以及四方结构(JCPDS 50-1089)和单 斜晶型(JCPDS 37-1484)复合的 $\mathrm{ZrO}_{2}$. 采用浸渍法在上 述载体上负载 $5 \mathrm{wt} \%$ 的 $\mathrm{Ni}$ 后, 仅在 $\mathrm{ZrO}_{2}$ 上出现微小的 $\mathrm{NiO}$ (JCPDS 04-0850)衍射峰, 表明 $\mathrm{Ni}$ 物种在各载体分 散良好. 不同载体负载的 $\mathrm{Ni}$ 催化剂的比表面积和孔结构 信息列于表 1 . 与 $5 \% \mathrm{Ni} / \mathrm{Al}_{2} \mathrm{O}_{3}$ 催化剂相比, 采用均匀沉 淀法制备的载体负载 $\mathrm{Ni}$ 后, 比表面积、平均孔径和孔体 积均较小.

\section{2. 催化剂的活性}

各 $\mathrm{Ni}$ 基催化剂与 $\mathrm{Ag} / \mathrm{Al}_{2} \mathrm{O}_{3}$ 耦合体系净化 $\mathrm{NO}_{x}$ 的活性 结果见图3. 作为对比, 考察了 $\mathrm{Ag} / \mathrm{Al}_{2} \mathrm{O}_{3}$ 催化剂上直接 以 $n-\mathrm{C}_{12} \mathrm{H}_{26}$ 为还原剂(记为 $n-\mathrm{C}_{12} \mathrm{H}_{26}-\mathrm{SCR}$ ) 时 $\mathrm{NO}_{x}$ 的净化效 率. 在该体系上, $525 \mathrm{~K}$ 时 $\mathrm{NO}_{x}$ 转化率仅为 $5 \%$, 未表现出 
低温起燃特性, 这可能由于 $n-\mathrm{C}_{12} \mathrm{H}_{26}$ 沸点较高, 较低温 度时易在催化剂表面累积导致活性降低 ${ }^{[16]}$. 随着温度 升高, $650 \mathrm{~K}$ 时 $\mathrm{NO}_{x}$ 转化率迅速增大并在673 823 K稳定 在 $78 \% . n-\mathrm{C}_{12} \mathrm{H}_{26}$ 经不同载体负载的 $\mathrm{Ni}$ 基催化剂重整后, 其在 $\mathrm{Ag} / \mathrm{Al}_{2} \mathrm{O}_{3}$ 上还原 $\mathrm{NO}_{x}$ 的效率发生显著变化. 经 $\mathrm{Ni} / \mathrm{Al}_{2} \mathrm{O}_{3}$ 重整后, 673 800 K时 $\mathrm{Ag} / \mathrm{Al}_{2} \mathrm{O}_{3}$ 净化 $\mathrm{NO}_{x}$ 的效率 较 $n-\mathrm{C}_{12} \mathrm{H}_{26}$-SCR 反应有所提高 (至 $90 \%$ ). $\mathrm{Ni} / \mathrm{ZrO}_{2}+$ $\mathrm{Ag} / \mathrm{Al}_{2} \mathrm{O}_{3}$ 耦合体系的活性温度窗口较 $\mathrm{Ag} / \mathrm{Al}_{2} \mathrm{O}_{3}$ 单独作用 时向低温移动了 $100 \mathrm{~K}$, 最高转化率达 $90 \%$. 可以看出, 该体系在573 773 K的典型柴油车尾气温度范围内 $\mathrm{NO}_{x}$ 转化率高于 $60 \%$, 具有相对理想的 $\mathrm{NO}_{x}$ 净化效果. 与 $\mathrm{Ni} / \mathrm{ZrO}_{2}+\mathrm{Ag} / \mathrm{Al}_{2} \mathrm{O}_{3}$ 体系相比, $\mathrm{Ni} / \mathrm{CeO}_{2}$ 与 $\mathrm{Ag} / \mathrm{Al}_{2} \mathrm{O}_{3}$ 的组合 进一步促进了 $\mathrm{NO}_{x}$ 的低温还原, 其活性温度窗口继续向 低温移动了约 $100 \mathrm{~K}$, 但 $660 \mathrm{~K}$ 以上的活性却显著降低 (550 K时 $\mathrm{NO}_{x}$ 转化率达最大值 $80 \%$, 后随温度升高而下 降). $\mathrm{Ni} / \mathrm{La}_{2} \mathrm{O}_{2} \mathrm{CO}_{3}$ 与 $\mathrm{Ag} / \mathrm{Al}_{2} \mathrm{O}_{3}$ 耦合作用时, 虽然在 375 475 K范围内 $\mathrm{NO}_{x}$ 转化率较 $\mathrm{Ni} / \mathrm{CeO}_{2}+\mathrm{Ag} / \mathrm{Al}_{2} \mathrm{O}_{3}$ 体系 提高约 $10 \%$, 但 $\mathrm{NO}_{x}$ 最高转化率降至 $60 \%$, 在高于 $500 \mathrm{~K}$ 时 $\mathrm{NO}_{x}$ 转化率也明显降低.

虽然 $\mathrm{H}_{2}$ 对 $\mathrm{Ag} / \mathrm{Al}_{2} \mathrm{O}_{3}$ 催化碳氢化合物选择性还原 $\mathrm{NO}_{x}$ 的作用机理仍饱受争议, 但其在低温条件下促进HCs部 分氧化并影响 $\mathrm{NO}_{x}$ 转化率的事实已被研究者广泛认 可 ${ }^{[24,31,44,45]} \cdot \mathrm{H}_{2}$ 对 $\mathrm{Ag} / \mathrm{Al}_{2} \mathrm{O}_{3}$ 上HC-SCR反应活性的影响与 反应条件密切相关, 如还原剂 $\mathrm{HCs}$ 和 $\mathrm{H}_{2}$ 浓度、 $\mathrm{HC} / \mathrm{NO}_{x}$ 比 例、反应温度及反应空速等. Lee等 ${ }^{[11]}$ 考察了 $\mathrm{H}_{2}$ 添加对 $2 \% \mathrm{Ag} / \mathrm{Al}_{2} \mathrm{O}_{3}$ 催化剂上 $\mathrm{C}_{3} \mathrm{H}_{6} / \mathrm{C}_{8} \mathrm{H}_{18}-\mathrm{SCR}\left(\mathrm{HC} / \mathrm{NO}_{x}=6\right)$ 反 应的影响, 发现 $523 \mathrm{~K}$ 时 $\mathrm{NO}_{x}$ 转化率随 $\mathrm{H}_{2}$ 浓度的增加而 显著提高至 $64 \%\left(\mathrm{H}_{2} / \mathrm{N}\right.$ 由 0 变为 10 时, $\mathrm{NO}_{x}$ 转化率由 $0 \%$ 升 至64\%). Sitshebo等 ${ }^{[37]}$ 在发动机台架上考察了 $\mathrm{H}_{2}$ 对蜂窝 载体负载的 $\mathrm{Ag} / \mathrm{Al}_{2} \mathrm{O}_{3}$ 催化剂净化 $\mathrm{NO}_{x}$ 效率的影响. 结果 显示, 低负荷条件 $\left(\mathrm{HC} / \mathrm{NO}_{x} \approx 0.9,17 \% \mathrm{O}_{2}, 375 \mathrm{~K}\right)$ 下 $\mathrm{NO}_{x}$ 净化效率随 $\mathrm{H}_{2}$ 浓度的增加 $\left(\mathrm{H}_{2} / \mathrm{N}=0 \sim 14\right)$ 而逐渐升高. 但 在高负荷条件 $\left(\mathrm{HC} / \mathrm{NO}_{x} \approx 0.5, \mathrm{O}_{2} 10.7 \%, 535 \mathrm{~K}\right)$ 下, $\mathrm{H}_{2} / \mathrm{N}$ 超过2.25时会因过量 $\mathrm{H}_{2}$ 促进碳氢化合物的完全氧化而导 致 $\mathrm{NO}_{x}$ 的转化率下降. Lee等 ${ }^{[11]}$ 进一步研究了柴油裂解催 化剂催化 $n-\mathrm{C}_{12} \mathrm{H}_{26}$ 部分氧化重整辅助 $\mathrm{C}_{3} \mathrm{H}_{6}$ 和 $\mathrm{C}_{12} \mathrm{H}_{26}$ 选择 性催化还原 $\mathrm{NO}_{x}$ 的反应, 结果表明, $\mathrm{H}_{2} / \mathrm{HCs}$ 的优化决定 了 $\mathrm{Ag} / \mathrm{Al}_{2} \mathrm{O}_{3}$ 还原 $\mathrm{NO}_{x}$ 的低温性能.

为此, 本文检测了 $650 \mathrm{~K}$ 时不同组合体系中 $\mathrm{H}_{2}$ 浓度、 $\mathrm{HC}$ 含量及 $\mathrm{NO}_{x}$ 转化率, 结果如表 2 所示. 在 $\mathrm{Ni} / \mathrm{Al}_{2} \mathrm{O}_{3}$ 催化 重整 $n-\mathrm{C}_{12} \mathrm{H}_{26}$ 时, 在反应的初始阶段约有 $10.3 \%$ 的 $\mathrm{HC}$ 被 完全氧化为 $\mathrm{CO}_{2}, \mathrm{H}_{2}$ 浓度为 $0.03 \%$, 产物中含有大量碳氢
物种, 为随后耦合的 $\mathrm{Ag} / \mathrm{Al}_{2} \mathrm{O}_{3}$ 催化剂上SCR反应的发生 提供还原剂 $\left(\mathrm{HC} / \mathrm{NO}_{x}\right.$ 高达 10$), \mathrm{NO}_{x}$ 转化率为 $57 \%$. 经 $\mathrm{Ni} / \mathrm{La}_{2} \mathrm{O}_{2} \mathrm{CO}_{3}$ 催化重整后, 产物中初始 $\mathrm{H}_{2}$ 浓度高达 $2.74 \%$, 而 $\mathrm{HC}$ 含量在所有测试的耦合体系中最低 $\left(\mathrm{HC} / \mathrm{NO}_{x}=5\right)$, 从而导致 $\mathrm{NO}_{x}$ 转化率也最低(仅为 $30 \%$ ). 反应 $3 \mathrm{~h}$ 后, 重整产物中 $\mathrm{H}_{2}$ 浓度急剧降低至 $0.98 \%$, 表明 $\mathrm{Ni} / \mathrm{La}_{2} \mathrm{O}_{2} \mathrm{CO}_{3}$ 催化重整的稳定性差. 经 $\mathrm{Ni} / \mathrm{CeO}_{2}$ 重整 $n-\mathrm{C}_{12} \mathrm{H}_{26}$ 的产物中 $\mathrm{H}_{2}$ 浓度 (2.05\%) 仅次于 $\mathrm{Ni} / \mathrm{La}_{2} \mathrm{O}_{2} \mathrm{CO}_{3}$, 为后续的 $\mathrm{SCR}$ 反应提供的 $\mathrm{HC}$ 浓度较低(仅比经 $\mathrm{Ni} / \mathrm{Al}_{2} \mathrm{O}_{3}$ 重整后高), 使得 $\mathrm{NO}_{x}$ 转化率也较低(约为 $52 \%$ ), 仅高于 $\mathrm{Ni} / \mathrm{Al}_{2} \mathrm{O}_{3}+\mathrm{Ag} / \mathrm{Al}_{2} \mathrm{O}_{3}$ 组合体系. 其中, $\mathrm{Ni} / \mathrm{ZrO}_{2}+\mathrm{Ag} / \mathrm{Al}_{2} \mathrm{O}_{3}$ 耦合体系中 $\mathrm{H}_{2}$ 浓度为 $1.12 \%, \mathrm{HC} / \mathrm{NO}_{x}=7.5$, 该 $\mathrm{H}_{2}$ 和还原 剂浓度可能处于较优的 $\mathrm{H}_{2} / \mathrm{HC}$ 比例范围内, 使得该体系 获得了最佳 $\mathrm{NO}_{x}$ 净化效率(650 $\mathrm{K}$ 时 $\mathrm{NO}_{x}$ 转化率高达 $88 \%$ ). 综合图3和表2可见, 重整催化剂的载体显著影响其重整 性能. 随重整产物中 $\mathrm{H}_{2}$ 浓度增加, 耦合 $\mathrm{SCR}$ 反应后 $\mathrm{NO}_{x}$ 低温净化活性升高. 但 $\mathrm{H}_{2}$ 产量增加的同时, 也促进了 $\mathrm{HC}$ 物种的完全氧化, 从而导致SCR反应中还原剂量减 少. 重整反应产物中 $\mathrm{H}_{2}$ 浓度的增加往往伴随着 $\mathrm{HC}$ 含量 的降低, 这可能表明过量的 $\mathrm{H}_{2}$ 促进了 HCs 的完全氧化. 此外需要指出, GC检测的结果表明, 重整产物多为C原 子数小于 4 的含氧碳氢化合物, 该类物种具备优异的 $\mathrm{NO}_{x}$ 还原性能.

\section{3. 重整催化剂氧化还原性能}

研究表明, $\mathrm{HC}$ 重整制氢反应体系中 $\mathrm{H}_{2}$ 的产率与催 化剂的氧化还原性能及活性组分与载体间的作用密切 相关. 鉴于此, 本文对不同载体负载的 $\mathrm{Ni}$ 基重整催化剂 进行了 $\mathrm{H}_{2}$-TPR测试, 结果见图4和表3. 可以看出, 在 $\mathrm{Ni} / \mathrm{Al}_{2} \mathrm{O}_{3}$ 催化剂上, $\mathrm{Ni}$ 组分与载体间较强的相互作用导 致了 $\mathrm{NiAl}_{2} \mathrm{O}_{4}$ 的形成, 该物种在 $800 \mathrm{~K}$ 以上才开始被还 原, 并在 800 1120 K 范围内出现较宽的 $\mathrm{H}_{2}$ 消耗峰. $\mathrm{Ni} / \mathrm{ZrO}_{2}$ 催化剂在550 800 K范围内出现重叠的双还原 峰, 其峰值分别位于 598 和 $703 \mathrm{~K}$; 前者归属于表面分散 的 $\mathrm{NiO}$ 物种的还原, 后者归属于与 $\mathrm{ZrO}_{2}$ 表面具有弱相互 作用的 $\mathrm{NiO}$ 物种的还原 ${ }^{[49]}$; 以上两峰对应的 $\mathrm{H}_{2}$ 消耗总量 为 $758 \mu \mathrm{mol} / \mathrm{g}$, 略低于 $\mathrm{NiO}$ 物种完全还原所需 $\mathrm{H}_{2}$ 量 $(845$ $\mu \mathrm{mol} / \mathrm{g}$, 随后以理论值表示), 表明该催化剂上 $\mathrm{Ni}$ 物种处 于高度分散状态, 与XRD结果一致. 在相近的温度下, $\mathrm{Ni} / \mathrm{CeO}_{2}$ 样品的还原也导致了双峰的形成, 其峰值分别 位于 608 和 $700 \mathrm{~K}$; 开始于 $450 \mathrm{~K}$ 的低温还原峰是由表面 吸附氧、表面 $\mathrm{CeO}_{2}$ 及均匀分散的 $\mathrm{NiO}$ 的还原造成的, 温 度较高的还原峰则对应于与载体相互作用的类体相 $\mathrm{NiO}$ 
与 $\mathrm{CeO}_{2}$ 的还原 ${ }^{[50]}$. 另外, $983 \mathrm{~K}$ 处还原峰可归属为 $\mathrm{Ni} / \mathrm{CeO}_{2}$ 样品上部分体相 $\mathrm{CeO}_{2}$ 的还原. $\mathrm{Ni} / \mathrm{La}_{2} \mathrm{O}_{2} \mathrm{CO}_{3}$ 样品 上位于 $975 \mathrm{~K}$ 处的强峰源于体相中 $\mathrm{La}^{3+}$ 的还原 ${ }^{[51]}$, $590 \mathrm{~K}$ 处的尖峰归属为表面 $\mathrm{NiO}$ 的还原, 其 $\mathrm{H}_{2}$ 消耗量约为792 $\mu \mathrm{mol} / \mathrm{g}$ (达理论值的94\%). 基于载体 $\mathrm{La}_{2} \mathrm{O}_{2} \mathrm{CO}_{3}$ 样品仅在 $975 \mathrm{~K}$ 附近出现还原峰, 可推测 $\mathrm{Ni} / \mathrm{La}_{2} \mathrm{O}_{2} \mathrm{CO}_{3}$ 催化剂上 $758 \mathrm{~K}$ 处的峰可能是与活性组分紧密接触的部分载体还 原所致.

通过对比不同氧化物负载的 $\mathrm{Ni}$ 催化剂的 $\mathrm{H}_{2}-\mathrm{TPR}$ 结 果, Sato等 ${ }^{[52]}$ 发现, $\mathrm{Ni} / \mathrm{Ce}_{0.5} \mathrm{Zr}_{0.5} \mathrm{O}_{2}$ 优异的氧化还原性能 决定了其重整乙醇的低温性能. De Lima等 ${ }^{[53]}$ 在分子水 平上证实了 $\mathrm{Pt} / \mathrm{CeZrO}_{2}$ 催化剂上表面氧物种在维持乙醇 氧化蒸汽重整反应稳定运行中的关键作用. 如图4所示, 均匀沉淀法制备的载体负载活性组分后, 虽然表面分散 的 $\mathrm{NiO}$ 还原峰(Peak 1)均位于 $600 \mathrm{~K}$ 左右, 但 $\mathrm{Ni} / \mathrm{CeO}_{2}$ 和 $\mathrm{Ni} / \mathrm{La}_{2} \mathrm{O}_{2} \mathrm{CO}_{3}$ 催化剂上该还原峰起始于 $450 \mathrm{~K}$, 较 $\mathrm{Ni} / \mathrm{ZrO}_{2}$ 样品的低(起始于 $540 \mathrm{~K}$ ), 表明前两种催化剂的低温氧 化还原性能更优异. 表3进一步给出了低温还原峰(Peak 1) $\mathrm{H}_{2}$ 消耗量占理论值的比例, $\mathrm{Ni} / \mathrm{ZrO}_{2}, \mathrm{Ni} / \mathrm{CeO}_{2}$ 及 $\mathrm{Ni} / \mathrm{La}_{2} \mathrm{O}_{2} \mathrm{CO}_{3}$ 催化剂对应该比值分别为 $27 \%, 64 \%$ 和 $94 \%$, 即可还原的表面 $\mathrm{NiO}$ 浓度显著增加, 低温氧化还原性能 随之增强. 由此可见, 重整催化剂低温氧化还原能力增 强, 重整反应产物中 $\mathrm{H}_{2}$ 浓度随之增大, 但也导致了可供 随后SCR反应利用的HCs浓度的降低(见表2). 该特性使 得耦合体系上 $\mathrm{NO}_{x}$ 还原温度窗口向低温移动, 最高 $\mathrm{NO}_{x}$ 转化率降低, 这清楚地表明了重整催化剂的氧化还原性 能在重整-SCR组合体系净化 $\mathrm{NO}_{x}$ 中的关键作用. $\mathrm{Ni} / \mathrm{ZrO}_{2}$ 呈现出适中的氧化还原性能, 其催化十二烷重整后的产 物中 $\mathrm{H}_{2}$ 及 $\mathrm{HC}$ 含量适中, 使得 $\mathrm{Ni} / \mathrm{ZrO}_{2}+\mathrm{Ag} / \mathrm{Al}_{2} \mathrm{O}_{3}$ 组合体 系在柴油车典型的排气温度范围内表现出优异的 $\mathrm{NO}_{x}$ 净 化效率.

\section{4. 催化剂的稳定性}

由表2可见, $\mathrm{Ni}$ 基催化剂上 $n-\mathrm{C}_{12} \mathrm{H}_{26}$ 重整过程中 $\mathrm{H}_{2}$ 产 率随着反应时间的延长而有所降低, 这很可能与催化剂 表面的积碳相关 ${ }^{[53]}$. 为此, 将 $873 \mathrm{~K}$ 温度下持续反应 $3 \mathrm{~h}$ 后的各催化剂进行了TG分析, 结果见图5. $\mathrm{Ni} / \mathrm{Al}_{2} \mathrm{O}_{3}$ 催化 剂失重率高达 $21.57 \%$, 据此算得平均积炭率约为 0.072
g-C/(g-cat.·h), 积炭现象严重. 另外, 该催化剂催化 $n-\mathrm{C}_{12} \mathrm{H}_{26}$ 重整产物中检测到了 $\mathrm{C}_{2} \mathrm{H}_{4}$ 的生成(约 $0.15 \%$ ), 而 其它重整催化剂上则没有该产物的生成,表明 $\mathrm{Al}_{2} \mathrm{O}_{3}$ 表面 的强酸性导致了重整制氢反应副产物 $\mathrm{C}_{2} \mathrm{H}_{4}$ 的生成, 加剧 了催化剂积炭 ${ }^{[46]}$. 与此相比, $\mathrm{ZrO}_{2}, \mathrm{CeO}_{2}$ 和 $\mathrm{La}_{2} \mathrm{O}_{2} \mathrm{CO}_{3}$ 负 载的 Ni催化剂的失重率明显降低, 分别为 $9.58 \%, 8.24 \%$ 和 $6.17 \%$. 由此可见, 重整催化剂的氧化还原性能不仅 影响氢气的产率, 同时也是决定重整过程中积炭效应的 重要因素, 强的氧化还原能力可有效抑制积炭发生, 与 文献结果一致 ${ }^{[47,48]}$. 另外 $\mathrm{Ni} / \mathrm{La}_{2} \mathrm{O}_{2} \mathrm{CO}_{3}$ 上可发生反应 $\mathrm{La}_{2} \mathrm{O}_{2} \mathrm{CO}_{3}+\mathrm{C} \rightarrow \mathrm{La}_{2} \mathrm{O}_{3}+2 \mathrm{CO}$, 促进了催化剂表面积炭 的氧化去除, 有可能进一步抑制积炭 ${ }^{[51]}$.

鉴于 $\mathrm{Ni} / \mathrm{ZrO}_{2}+\mathrm{Ag} / \mathrm{Al}_{2} \mathrm{O}_{3}$ 较为理想的 $\mathrm{NO}_{x}$ 净化效果, 图6给出了该催化组合体系在重整-SCR反应过程中 $\mathrm{H}_{2}$ 浓 度和 $\mathrm{NO}_{x}$ 转化率随时间的变化, 其中重整反应温度为 $773 \mathrm{~K}, \mathrm{NO}_{x}$ 还原温度为 $650 \mathrm{~K}$. 由图中可见, 在反应开始 的 $2 \mathrm{~h}$ 内重整反应产物中 $\mathrm{H}_{2}$ 浓度和 $\mathrm{NO}_{x}$ 转化率均有所下 降, 但降幅不显著. 随后的 $3 \mathrm{~h}$ 反应中, $\mathrm{H}_{2}$ 浓度保持在 $1 \%$ 左右, $\mathrm{NO}_{x}$ 转化率也基本维持在 $88 \%$ 左右. 随着反应时间 延长, $10 \mathrm{~h}$ 后 $\mathrm{H}_{2}$ 浓度明显下降至约 $0.2 \%$, 随后缓慢下降. $\mathrm{H}_{2}$ 浓度的降低导致了 $\mathrm{NO}_{x}$ 转化率的下降, 但其降幅远低 于前者. 反应进行 $24 \mathrm{~h}$ 后, $\mathrm{NO}_{x}$ 转化率可稳定在 $70 \%$ 左右. 连续反应 $24 \mathrm{~h}$ 后 $\mathrm{Ni} / \mathrm{ZrO}_{2}$ 样品的热重结果显示其失重率 达 $16.5 \%$, 存在明显的积炭现象, 表明其性能有待进一 步改进.

\section{4. 结论}

载体性质显著影响了 $\mathrm{Ni}$ 基重整催化剂的氧化还原 性能, 从而明显改变了其催化 $n-\mathrm{C}_{12} \mathrm{H}_{26}$ 重整的反应产物 中 $\mathrm{H}_{2}$ 及小分子 HCs 含量, 进而影响了燃油重整-SCR耦合 体系的 $\mathrm{NO}_{x}$ 净化效果. $\mathrm{Ni} / \mathrm{ZrO}_{2}$ 催化 $n-\mathrm{C}_{12} \mathrm{H}_{26}$ 重整产物中 $\mathrm{H}_{2}$ 及 $\mathrm{HCs}$ 浓度符合 SCR 反应所需的最佳比例范围 $\left(\mathrm{H}_{2}\right.$ $1.1 \%, \mathrm{HC} / \mathrm{NO}_{x}=7.5$ ), 使得 $\mathrm{Ni} / \mathrm{ZrO}_{2}+\mathrm{Ag} / \mathrm{Al}_{2} \mathrm{O}_{3}$ 耦合体系 在柴油车典型的排气温度范围内表现出良好的 $\mathrm{NO}_{x}$ 的净 化效率. 然而 $\mathrm{Ni}$ 基催化剂的积炭导致了其产氢性能降 低, 从而影响了燃油重整-SCR 组合体系净化 $\mathrm{NO}_{x}$ 的 效率. 